Swarthmore College

Works

Winter 1992

\title{
Reform In The International Food Aid Regime: The Role Of Consensual Knowledge
}

Raymond F. Hopkins

Swarthmore College, rhopkin1@swarthmore.edu

Follow this and additional works at: https://works.swarthmore.edu/fac-poli-sci

Part of the Political Science Commons

Let us know how access to these works benefits you

\section{Recommended Citation}

Raymond F. Hopkins. (1992). "Reform In The International Food Aid Regime: The Role Of Consensual Knowledge". International Organization. Volume 46, Issue 1. 225-264. DOI: 10.1017/S0020818300001491 https://works.swarthmore.edu/fac-poli-sci/177

This work is brought to you for free by Swarthmore College Libraries' Works. It has been accepted for inclusion in Political Science Faculty Works by an authorized administrator of Works. For more information, please contact myworks@swarthmore.edu. 


\section{Reform in the international food aid regime: the role of consensual knowledge Raymond F. Hopkins}

Achieving food security worldwide has emerged as a central goal governing the use of food aid in recent years. In large part, this is attributable to shifts in public pressures that have resulted from an increase in information about the incidence, causes, and costs of hunger and from detailed studies concerning the beneficial and harmful effects of food aid. ${ }^{1}$ Since the 1950s, the opinion of policymakers and much of the influential public in major donor states has evolved in favor of using food aid as a vehicle to foster development-oriented projects designed to alleviate the long-term food security problems of recipients, rather than merely serving as a remedy for the recipients' immediate food shortages and an outlet for the donors' disposal of surplus food commodities.

An international epistemic community, consisting of economic development specialists, agricultural economists, and administrators of food aid who not only share this goal but also have a common scientific orientation grounded in standard social science, played a major role in bringing about this shift in

This article draws on ideas published in my earlier article, "The Evolution of Food Aid," Food Policy 9 (November 1984), pp. 345-62, and on papers presented at the meetings of the American Political Science Association, Washington, D.C., September 1987, and the International Studies Association, London, April 1989. I am grateful to Stephen Krasner, Peter Cowhey, Peter Katzenstein, Peter Haas, and M. J. Peterson for their comments and suggestions. I am also deeply indebted to Owen Cylke, Jon O'Rourke, and their colleagues at the Agency for International Development, an organization that provided a grant to Swarthmore College for the purpose of organizing a series of conferences that were held in preparation for the 1990 farm bill and focused on changes in the PL480 legislation.

1. For examples of these shifts, see the testimony of Owen Cylke, the acting assistant administrator for food aid at the Agency for International Development (AID), in U.S. Congress, Senate Committee on Agriculture, Nutrition, and Forestry, Preparation of the 1990 Farm Bill, PL480: Hearings Before the Committee on Agriculture, Nutrition, and Forestry, 101st Congress, 1st sess., 1989; World Bank and World Food Programme (WFP), "Food Aid in Sub-Saharan Africa," draft of a joint study, Washington, D.C., September 1990; Alan Berg, Malnourished People: A Policy View (Washington, D.C.: World Bank, 1981); and Vernon W. Ruttan, Why Food Aid? Surplus Disposal, Development Assistance, and Basic Needs (Baltimore, Md.: Johns Hopkins University Press, forthcoming), chaps. 1 and 2. Cylke's testimony was built on a series of workshops and conferences held in 1988-89 and attended by scholars on food aid. The participants' interaction is 
opinion. ${ }^{2}$ Over the years, the epistemic community members have undertaken extensive analyses of the effects of food aid and of the nutritional needs of recipient countries, bridged divisions among and within states over priorities and criteria for providing food aid, proposed more efficient methods for supplying the aid, and promoted their goal of development-oriented uses of food aid. Reform in the principles, rules, and practices of the international food aid regime testifies to the existence of a significant role for epistemic communities in international affairs and to the impact of their ideas on politics. The partial, incomplete quality of reform, however, also illustrates how and under what circumstances the organized subnational interest groups can succeed in their efforts to resist changes, even when those changes are widely accepted and applauded as serving desirable collective ends.

A study of the evolution of food aid and the role played by intellectual critics in its reform illustrates three points about the process of change relevant to the study of international institutions. First, criticisms of norms and principles that originally shaped the regime have fostered change. ${ }^{3}$ The norms governing food aid exchanges, for example, arose from a set of national government policies in which unilateral decision making heavily conditioned international outcomes; in contrast, reforms have had a transnational basis. A major debate between domestic agricultural policy interest groups and development-oriented theorists and agencies has shaped international food aid policy and criteria for judging efficiency in resource allocation for both donors and recipients. ${ }^{4}$ Like

an excellent example of the paths by which an epistemic community can nurture consensual knowledge. The epistemic community's advocacy statements for policy reform and greater policy coordination in the food aid donor community were reflected, for example, in the July 1990 farm bill reforms for PL480 as set forth by both the Senate and the House and in the final bill that was passed by Congress in October 1990 and signed into law in December 1990. The community's ideas are also most incorporated in the position taken by the Cairns Group in the ongoing Uruguay Round negotiations of the General Agreement on Tariffs and Trade (GATT).

2. For a discussion of the defining qualities of an epistemic community, see the following works by Peter M. Haas: "Introduction: Epistemic Communities and International Policy Coordination," in this issue of $I O$; and "Do Regimes Matter? Epistemic Communities and Mediterranean Pollution Control," International Organization 43 (Summer 1989), pp. 377-404.

3. For a discussion of the defining qualities of regimes and their capacity to change, see Stephen D. Krasner, ed., International Regimes (Ithaca, N.Y.: Cornell University Press, 1983), chap. 1; and Oran R. Young, "The Politics of International Regime Formation: Managing Natural Resources and the Environment," International Organization 43 (Summer 1989), pp. 349-75. In my article, I sometimes use the terms "regime" and "institution" interchangeably. While some might question this practice, there is considerable overlap in the two concepts, since a regime is one type of institution. Moreover, both concepts emphasize the subjective elements of structure in human affairs, rather than the objective or externalized elements; that is, they look at the distribution of ideas, beliefs, goals, and so forth, rather than the distribution of wealth, military force, and the like. My own understanding of the term "institution" derives from Talcott Parsons' The Social System (New York: Free Press, 1964), in which Parsons refers to institutions as entities characterized by "structured complementarity" among roles (p. 39). Neither "regime" nor "institution" is a term that requires an exclusive focus on formal organizations or legal documents in order to discuss and evaluate the reliability or cost benefits of international collaboration.

4. See D. Gale Johnson and G. Edward Schuh, eds., The Role of Markets in the World Food Economy (Boulder, Colo.: Westview Press, 1983). 
many issues among states, the issues in this case have involved two-level bargaining. ${ }^{5}$ During the period from 1958 to 1990, dozens of international conferences on food aid were held. While some were formal and involved experts in national governments and in international bodies such as the United Nations (UN) and World Bank, others were less formal and sponsored by business or academic groups. From the debates at these conferences, a consensus regarding the desirable norms and rules emerged among certain development specialists, an epistemic community on food aid. This consensus has provided the impetus for reform of the earlier norms and practices that were based on surplus disposal of grains.

Second, principles of the food aid regime have become institutionalized. During the 1980s, when food aid accounted for over 10 percent of official development assistance and cost about $\$ 3$ billion annually, about twenty-five countries were donors and over a hundred were recipients of food. Given the number of states involved in food aid, national and international negotiations were necessary to avoid mutually disadvantageous outcomes. The principles of the regime thus became institutionalized through the creation of the World Food Programme (WFP), an intergovernmental body; through the adoption of the Food Aid Convention, an international treaty setting a floor for food aid donations; through the signing of memorandums of agreement and legal contracts among hundreds of countries; and through the ratification of increasingly complex national legislation. Such formal aspects of the food aid regime fully satisfy the requirements of an international regime proposed by most analysts. ${ }^{6}$

Third, the dissemination of information about the incidence and causes of hunger has had an impact on popular opinion, and this in turn has fostered change in the food aid rules and practices. In the 1980s, an estimated 730 million people's diets in developing countries lacked sufficient calories.7 Historically, one of the debates about food aid concerned whether the problem of hunger stemmed from inadequate food production (a supply problem) or from poverty and the inability of poor people to secure food (a demand problem). ${ }^{8}$ According to the developmentalists, it is possible for the international community to produce enough food to feed the world populace adequately, particularly through the application of improved technology and

5. See Robert D. Putnam, "Diplomacy and Domestic Policy: The Logic of Two-Level Games," International Organization 42 (Summer 1988), pp. 427-60.

6. For a discussion of the formal, lawlike attributes of regimes, see Robert O. Keohane, After Hegemony: Cooperation and Discord in the World Political Economy (Princeton, N.J.: Princeton University Press, 1984); and Friedrich Kratochwil and John Gerard Ruggie, "International Organization as an Art of the State: A Regime Critique," International Organization 40 (Autumn 1986), pp. 753-76.

7. World Bank, Poverty and Hunger (Washington, D.C.: World Bank, 1986).

8. See Amartya K. Sen, Poverty and Famines: An Essay on Entitlement and Deprivation (Oxford: Clarendon Press, 1981); and Susan George, "Food Strategies for Tomorrow," mimeograph, the Global Hunger Project, New York, December 1987. 
scientific understanding of farm systems. ${ }^{9}$ The broad consensus on this point has provided a link between the epistemic community developmentalists and the public in various parts of the world. Evidence that public interest in ending hunger has grown in recent decades is reflected in responses to surveys, in pressures placed on legislators by their constituencies, and in the organized activities of lobbying groups, some of which are worldwide in scope, such as the Hunger Project. Yet neither the acceptance of the link between poverty and hunger nor the popular support for efforts to curb hunger can ensure that food aid will have its intended effects. One of the dilemmas of food aid is that efforts to provide it have often ended in "deadlock" or mutual loss. ${ }^{10}$ And one of the paradoxes is that the aid, when given for military or ideological reasons, has often led to an increase in hunger-as occurred, for example, in Vietnam in 1965-73, Bangladesh in 1974, and El Salvador in 1988-89. ${ }^{11}$

The arguments presented below are divided into three parts. The first section of the article reviews the political history of the food aid regime and describes how the regime principles and rules evolved. The second section discusses the epistemic community's knowledge base in shaping the food aid regime. It argues that as relevant "knowledge" changed, consensus about particular regime features also changed and brought about the demand for new regime practices, such as the use of triangular transactions and the purchase of food from local producers. The third section explores the impact of the epistemic community on government policies and views with respect to four issues concerning food aid: disincentives, the efficiency of resource transfers, the criteria for allocation of food aid, and the conditions imposed on recipients. The pattern of allocation by the United States, the largest food aid donor, illustrates clearly the claim that neither ideas nor power shifts alone are sufficient for explaining change in international behavior.

\section{The food aid regime from 1954 to 1990}

The origins of food aid lay in U.S.-led efforts to address simultaneously several international problems of recovery from war, economic crisis, and food trade imbalance. From 1945 to the early 1950s, recovery from World War II

9. See William W. Murdoch, The Poverty of Nations: The Political Economy of Hunger and Population (Baltimore, Md.: Johns Hopkins University Press, 1980); and John Mellor et al., eds., Accelerating Food Production in Sub-Saharan Africa (Baltimore, Md.: Johns Hopkins University Press, 1987).

10. See Kenneth A. Oye, ed., Cooperation Under Anarchy (Princeton, N.J.: Princeton University Press, 1986).

11. See Mitchel Wallerstein, Food for War: Food for Peace (Cambridge, Mass.: MIT Press, 1980); Dean McHenry and Kai Bird, "Food Bungle in Bangladesh," Foreign Policy 27 (Summer 1977), pp. 72-88; and testimony of Raymond F. Hopkins, in U.S. Congress, House Select Committee on Hunger, Restructuring Food Aid: Hearings Before the House Select Committee on Hunger, 101st Congress, 1st sess., 1989. 
encouraged massive noncommercial movements of food. Food shortages in some countries were juxtaposed with surpluses in others, principally the United States. ${ }^{12}$ Following a decade of ad hoc arrangements for food aid, on 10 July 1954, President Eisenhower signed Public Law 480 (PL480), an act that was subsequently built into U.S. farm legislation and established the United States as a principal and permanent provider of food aid. During this period, Canada was the only other substantial donor. Thus, the motivation and ideas predominant in the establishment of the regime derived from U.S. domestic material interests. Development economists were largely skeptical outsiders to its design. PL480 authorized the use of U.S. government-owned surplus agricultural commodities as part of the American foreign assistance program. From 1955 to 1964, it drew funds from the agricultural budget to do this; since then, it has drawn funds from the foreign affairs account.

Four equally important purposes were mandated for food aid: to serve foreign policy needs, to promote economic development, to establish overseas markets for American agricultural products, and to help alleviate hunger overseas. With regard to the initial regime principles, these purposes implied that food aid (1) should be provided from the donors' own surplus stocks, (2) should supplement the usual commercial food imports in recipient countries, (3) should be given under short-term commitments sensitive to the political and economic goals of donors, and (4) should directly feed hungry people. This initial package of principles rested on the theoretical supposition that the levels of food production-largely wheat production-in certain rich, exporting states were in excess both of domestic consumption needs and of commercial export needs. Hence, some stocks could be transferred by "special transactions" to recipient states in which production and import levels failed to meet domestic consumption needs. ${ }^{13}$

The inaugural legislation combined three long-standing impulses or motivations. The first, a humanitarian one, created a permanent instrument to serve the commitment to provide food to peoples threatened by famine and malnutrition. National surpluses, which lower the price of domestic products, made it politically and economically more attractive to act charitably through food provisions. The charitable impulse institutionalized by PL480 was not new, however. In the early twentieth century, for example, the United States, already a food exporter, provided emergency food aid to China. After each of the world wars, the United States helped prevent famines in war-devastated areas. ${ }^{14}$ The second motivation for U.S. food aid, one that existed perpetually

12. See Susan B. Epstein, "Food for Peace, 1954-1986: Major Changes in Legislation," Congressional Research Service, Washington, D.C., 30 April 1987; Ann-Marie Bairstow, "A History of United States Food Aid, 1812-1954," U.S. Agency for International Development, Washington, D.C., August 1988; and Trudy Heskamp Peterson, Agricultural Exports, Farm Income, and the Eisenhower Administration (Lincoln: University of Nebraska Press, 1979).

13. John Cathie, The Political Economy of Food Aid (New York: St. Martin's Press, 1982).

14. Kathleen Ann Cravero, "Food and Politics: Domestic Sources of U.S. Food Aid Policies, 1949-1979," Ph.D. diss., Fordham University, Bronx, N.Y., 1982. 
since World War II, was the use of subsidized transfers of U.S. food to reduce excess American food stocks. The price support system adopted in the 1930s, which encouraged expanded production, and the rising price of food in the world markets during the 1940s, which was reflected domestically, resulted in large government-held surpluses in the $1950 \mathrm{~s}^{15}$ Food aid addressed this problem of surpluses. It subsidized the development of foreign markets for these goods, thereby protecting U.S. farmers by creating additional demands and keeping prices from falling. The increase in exports then lowered the cost of U.S. farm programs involving the government's purchase and storage of excess food stocks. The third motivation was diplomatic and ideological. The American interest in sending food to Europe and Japan in the 1950s was based on concerns not only related to economic recovery but also related to security. Food aid could support friendly governments and help fight the global battle against communism.

Thus, American "interests" arising from the Cold War and agricultural surpluses were combined with liberal humanitarian ideals. Hubert Humphrey, a prominent liberal U.S. senator in the 1950s, perhaps best characterized the "climate" among public leaders sponsoring food aid when he argued that supplying food to other countries could be "a great asset for checking communist aggression" and offered the following rationale: "Communism has no greater ally than hunger; and democracy and freedom no greater ally than an abundance of food."'

As the subsequent sections of this article make clear, each of the four original principles of the food aid regime has been challenged and changed, partly in response to structural factors but also according to prescriptions arising from a community of development specialists studying food aid. In 1963, when the WFP was established to coordinate a special portion of food aid, the aid was to be used by recipient governments in agricultural and other projects that would help needy people improve their lives. This agency, a joint undertaking of the UN General Assembly and the Food and Agriculture Organization (FAO), began with less than $\$ 100$ million to use for emergency and development projects during a three-year period. By the late 1980s, the WFP had dramatically increased its regime role. It had become a large multilateral assistance agency, second only to the World Bank in size, and was now transferring resources to less developed countries (LDCs) in amounts exceeding $\$ 1$ billion annually. It had also become the major arena in which new norms for all food aid were being articulated. Among the factors that facilitated the changes in the regime role and norms was a decrease in the prominence of the United States as a food aid donor in the 1970s, with the result that the regime became more multilateral.

15. Epstein, "Food for Peace."

16. Hubert Humphrey, testimony before the Senate Committee on Agriculture and Forestry, 16 July 1953, on considerations of S. 2249 authorizing the use of surplus commodities for foreign assistance; cited by Ruttan in Why Food Aid? p. 1. 
The 1970s and 1980s were marked by numerous behavioral changes in food aid, five of which involved declines: the U.S. share of world food aid dropped (see Figure 1); the U.S. share of costs for world food aid dropped; the absolute tonnage dropped (see Tables 1 and 2); the share of food aid in cereal trade dropped; and the ratio of food aid to total official development assistance (ODA) dropped. For example, between 1958 and 1968, the U.S. share of world food aid was between 90 and 95 percent and averaged nearly 15 million metric tons, most of which went to a group of ten to fifteen countries. In the 1980s, the United States reduced its volume share to between 50 and 65 percent, and its cost share also fell to less than 50 percent of the world's cost for food aid. Ironically, the total volume of world food aid declined when the burden of providing it became more widely shared and the cost of food and transport declined. In addition, while food aid accounted for 15 to 25 percent of grain trade and represented close to 20 percent of the total ODA in the $1950 \mathrm{~s},{ }^{17}$ it accounted for only 5 percent of grain trade and 10 percent of ODA in the 1980s.

As all of these measures of food aid shrank, however, the types of end use and modalities for delivering food aid grew in complexity and the food regime expanded in scope. In 1989, about twenty-five countries provided food and over a hundred received it. The number of recipients reflected the fact that the number of cases of chronic malnourishment had not declined. Estimates of those suffering from hunger in the 1980s ranged from 250 million to over a billion. $^{18}$

The overall decline in food aid proved useful in facilitating a shift in regime goals. Indeed, as food aid proved less important to producer groups, this made it easier for the regime to abandon surplus disposal as a principal element in rhetoric about food aid and to focus instead on food security goals aimed at economic development and the long-term alleviation of hunger. Two other factors helped account for the shift in goals.

First, in November 1974, following the panic over rising world food prices during the previous two years, a world food conference was held. The participants agreed that meeting long-term food security needs should be given priority and made several decisions regarding WFP leadership and resources, decisions that facilitated research and networking among food aid specialists. One of the decisions was to create a new international governing committee,

17. See International Wheat Council (IWC), Rules of Procedure: 1981 Protocol for the First Extension of the Food Aid Convention, 1980 (London: IWC, 1981); Organization for Economic Cooperation and Development (OECD), Development Cooperation: 1985 Report (Paris: OECD, December 1985), pp. 137-56; and OECD, Development Cooperation: 1989 Report (Paris: OECD, December 1989).

18. See Thomas T. Poleman, "World Hunger: Extent, Causes, and Cures," in Johnson and Schuh, The Role of Markets in the World Food Economy, pp. 41-89; World Bank, Poverty and Hunger; Robert Kates, World Hunger Report, 1989 (Providence, R.I.: Brown University Press, 1989); and National Research Council, Food Aid Projections for the Decade of the 1990s (Washington, D.C.: National Academy Press, 1989). 
the Committee on Food Aid Policies and Programs. The new committee was to consist of thirty member states and would be responsible for establishing the principles for food aid, for providing guidance both to donors and to recipients, and for carrying out the tasks initially mandated to its predecessor body, the WFP Intergovernmental Committee or "parliament." Since its inception, the Committee on Food Aid Policies and Programs has met twice a year to approve the two- to five-year food aid projects to be supported by the WFP and to discuss general principles and norms for all food aid, including that provided through bilateral agreements and accounting for 75 percent of the world's total food aid. Another decision made by the conference participants was to establish special financial bodies to channel investments to farmers involved in small-scale production. Accordingly, the International Fund for Agriculture Development was created in 1977.

Second, there was an increase in policy coordination efforts outside the WFP Committee on Food Aid Policies and Programs. In the late 1970s, the World Bank Consultative Group, which met frequently to coordinate aid to individual countries, began to discuss and approve food aid in selected cases, such as that involving Bangladesh. In the 1980s, the European Community (EC) Parliament met and voted to allow cash to be substituted for food aid when appropriate. During this same period also, the United States, Canada, and EC members began to hold semiannual meetings focusing on food aid. This facilitated policy coordination among the major donors and encouraged them to pursue complementary policies on a shared goal-that of long-term hunger alleviation. ${ }^{19}$

While the shift to this goal has been less than complete in the United States, which has an historical legacy of multiple objectives pursued through food aid, it has steadily gained momentum. In 1990, it became the central reform element in legislation to change PL480, as contained in the Senate farm bill sponsored by Patrick Leahy and Richard Lugar and in the House version of the bill supported by Samuel Gejdenson and the Foreign Affairs Committee. The legislation, which was passed in October 1990 and signed into law in December 1990, calls for limiting "sales" of food to middle-income countries and targeting grant aid-now the bulk of U.S. food aid-to countries categorized as "food insecure" on the basis of low caloric intake and income criteria.

\section{Consensual knowledge and the reform agenda}

The evolving consensus about the uses of food aid has stemmed from academic studies and from the experience of officials administering programs in donor and recipient states. Motivation for change has come principally from a

19. Raymond F. Hopkins, "The Evolution of Food Aid," Food Policy 9 (November 1984), pp. 345-62. 


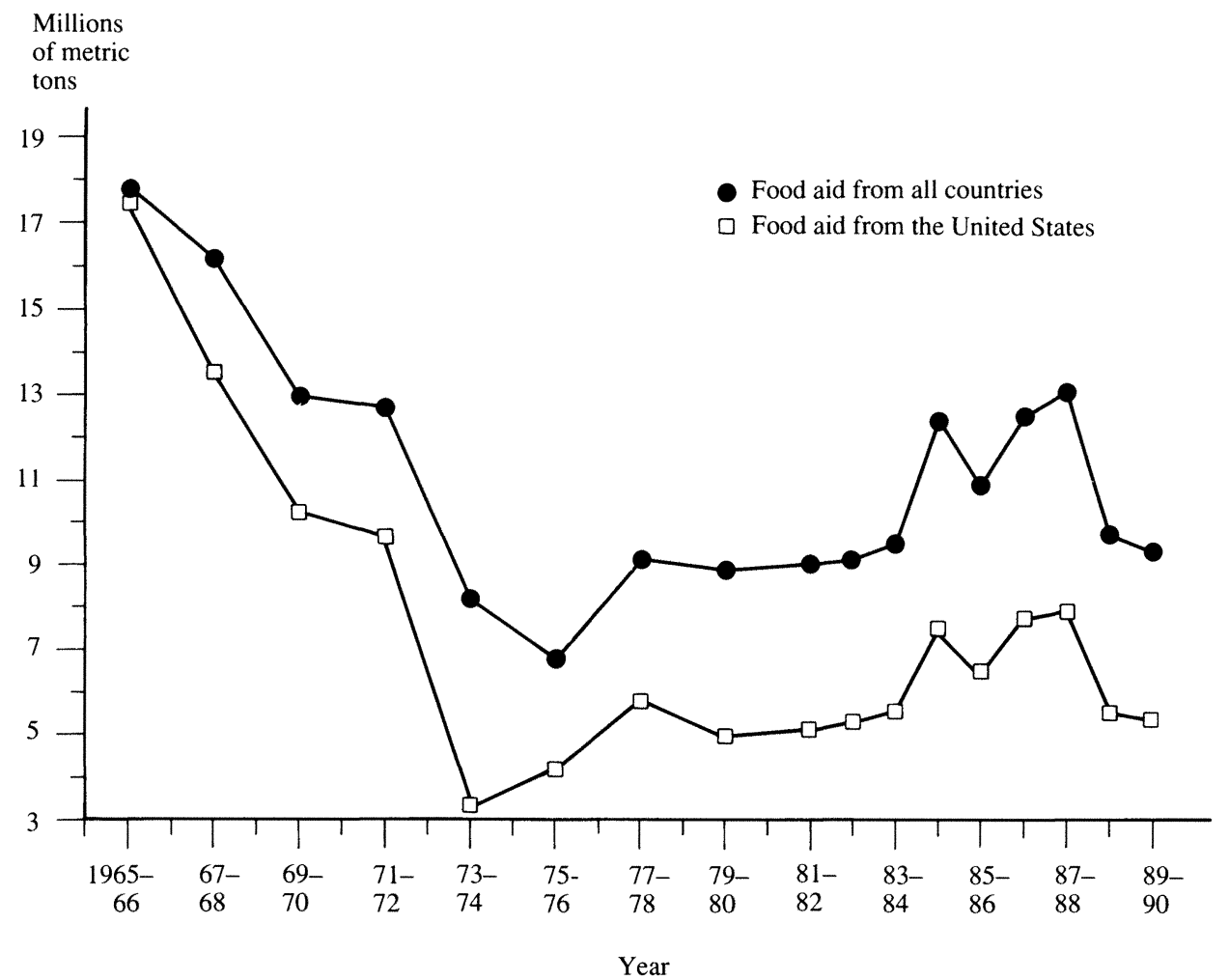

FIGURE 1. Millions of metric tons of cereal provided by the United States and other countries, 1965-66 through 1989-90

Sources. See Tables 1 and 2. 
TABLE 1. Millions of metric tons of cereal provided by principal food aid donors, 1965-66 through 1979-80

\begin{tabular}{|c|c|c|c|c|c|c|c|c|}
\hline Argentina & - & - & 0.027 & 0.013 & 0.010 & - & 0.032 & 0.038 \\
\hline Canada & 0.401 & 0.798 & 0.663 & 1.093 & 0.664 & 1.034 & 0.884 & 0.730 \\
\hline EC members & - & - & 1.356 & 0.978 & 1.209 & 0.928 & 1.374 & 1.206 \\
\hline Japan & - & - & 0.395 & 0.731 & 0.350 & 0.033 & 0.135 & 0.688 \\
\hline Soviet Union & na & 1.714 & na & na & 2.200 & na & 0.200 & na \\
\hline Other countries & - & - & 0.064 & 0.266 & 0.335 & 0.271 & 0.242 & 0.473 \\
\hline Total & 17.725 & 16.221 & 12.920 & 12.727 & 8.241 & 6.847 & 9.211 & 8.887 \\
\hline U.S. percent of total & $97.7 \%$ & $83.3 \%$ & $78.6 \%$ & $74.0 \%$ & $38.7 \%$ & $62.4 \%$ & $65.0 \%$ & $60.1 \%$ \\
\hline
\end{tabular}

${ }^{\mathrm{a}}$ Dash $=$ none or negligible; $\mathrm{na}=$ data not available.

Sources. For Canada in 1965-66 and 1967-68, Canadian Department of Agriculture, mimeograph, Ottawa, June 1979. For the United States in 196566, U.S. Department of Agriculture (USDA), U.S. Agricultural Exports Under Public Law 480 (Washington, D.C.: Government Printing Office, October 1974), Table 5. For Australia, Soviet Union, and Sweden (wheat only) in 1967-68, International Wheat Council, Record Operations of Member Countries Under the International Wheat Agreement (London: International Wheat Council, 1978), pp. 15-17. For the United States in 1967-68, U.S. Congress, American Food Assistance: Report of the U.S. Senate Committee on Agriculture and Forestry (Washington, D.C.: Government Printing Office, August 1976), p. 34. For all other data, USDA, Foreign Agricultural Trade of the United States (Washington, D.C.: Government Printing Office, June 1979), p. 73; USDA, World Food Needs and Availabilities, 1989-90: Summer Update (Washington, D.C.: Government Printing Office, August 1989), p. 18; and United Nations Food and Agriculture Organization (FAO), Food Aid in Figures, 1989, vol. 7/1 (Rome: FAO, 1990). 
TABLE 2. Millions of metric tons of cereal provided by principal food aid donors, 1981-82 through 1989-90"

\begin{tabular}{|c|c|c|c|c|c|c|c|c|c|}
\hline Argentina & 0.020 & 0.033 & 0.030 & 0.051 & 0.044 & 0.024 & 0.026 & 0.035 & 0.030 \\
\hline Canada & 0.600 & 0.843 & 0.817 & 0.943 & 1.216 & 1.240 & 1.062 & 1.000 & 0.900 \\
\hline EC members & 1.602 & 1.596 & 1.917 & 2.505 & 1.614 & 1.884 & 2.483 & 2.000 & 2.000 \\
\hline Japan & 0.507 & 0.517 & 0.445 & 0.295 & 0.450 & 0.529 & 0.547 & 0.380 & 0.350 \\
\hline Soviet Union & na & na & na & na & 0.010 & na & na & na & na \\
\hline Other countries & 0.466 & 0.438 & 0.442 & 0.627 & 0.525 & 0.599 & 0.657 & 0.432 & 0.380 \\
\hline Total & 9.140 & 9.238 & 9.849 & 12.511 & 10.949 & 12.579 & 13.160 & 9.757 & 9.400 \\
\hline U.S. percent of total & $58.4 \%$ & $58.2 \%$ & $57.4 \%$ & $60.2 \%$ & $61.0 \%$ & $62.5 \%$ & $60.4 \%$ & $56.4 \%$ & $57.4 \%$ \\
\hline
\end{tabular}

${ }^{a}$ na $=$ data not avaliable.

Sources. For 1988-89 and 1989-90, figures are estimates based on minimum contributions under the 1986 Food Aid Convention, budgetary allocations, historical patterns, current food aid policies, and information drawn from a variety of sources. For other years, U.S. Department of Agriculture (USDA), Foreign Agricultural Trade of the United States (Washington, D.C.: Government Printing Office, June 1979), p. 73; USDA, World Food Needs and Availabilities, 1989-90: Summer Update (Washington, D.C.: Government Printing Office, August 1989), p. 18; and United Nations Food and Agriculture Organization (FAO), Food Aid in Figures, 1989, vol. 7/1 (Rome: FAO, 1990). 
development-oriented epistemic community of food aid specialists. Nevertheless, commodity groups, grain traders, farmers, shipping firms, marketing managers in LDCs, and other interest groups seeking specific economic gains have also made proposals to shape food aid practices.

Debates between the developmentalists and the interest groups have tended to focus on the following: the degree to which food aid is considered "special"; the criteria on which allocation of food aid is based; the mode of delivery of food aid; the extent to which its supply is reliable; the extent to which it has an adverse (disincentive) effect on food production in recipient countries; and the types of conditionality that can be reasonably and legitimately associated with food aid transactions. While some of the arguments for change are based on lessons learned from past "mistakes," ${ }^{20}$ others have arisen in response to a heightened awareness of circumstances that improve the opportunities for food aid to have a beneficial impact. The improved supply situation in both donor and recipient states, for example, opened up a range of possible choices for change.

While it is clear that an epistemic community of food aid specialists played an important role in fostering change in international food aid policy, tracing the membership of the community over a forty-year period and depicting the contributions of specific members is complicated by the fact that some people's careers moved them inside the group for a brief time, while other people played a vital role over their lifetimes. For example, many key officials and respected academics-such as D. Gale Johnson, University of Chicago economist and provost-made intellectual contributions, but these have often been sufficiently episodic or redundant to the contributions of other, longer-term participants that their inclusion in the community is debatable. Another problem in tracing the community stems from the fact that details of meetings among and reports issued by development specialists on food aid in the $1950 \mathrm{~s}$ and 1960s are less accessible, but these details are perhaps less relevant, since the major thrust for change in the food aid regime occurred in subsequent decades.

One of the most prominent early members of the epistemic community, notable for his many contributions toward making food aid a tool of economic development, was Hans Singer. Singer assumed a key role in the community first in the late 1950s while a UN official and continued in later decades to play a crucial role in food aid reform. ${ }^{21}$ His numerous books and hundreds of articles have served to illuminate the many opportunities for innovation. From his earliest book, Men Without Work, an investigation of conditions in Germany in the 1930s, through his 1950 essay entitled "Distribution of Gains Between

20. For an analysis of the impact that memories of past mistakes have on decision making, see Ernest R. May, "Lessons" of the Past: The Use and Misuse of History in American Foreign Policy (New York: Oxford University Press, 1973).

21. Regarding the key role played by Singer, see Edward Clay and John Shaw, eds., Poverty, Development, and Food: Essays in Honor of H.W. Singer (London: Macmillan, 1987). 
Investing and Borrowing Countries," published in the American Economic Review, to his 1987 volume reviewing and summarizing the earlier work on food aid, Singer has consistently sought to integrate food aid into general economic assistance, to eliminate its negative effects on recipient countries, and to channel it toward economic development in poor nations. ${ }^{22}$ Indeed, virtually all of the arguments about change in regime principles discussed below have been articulated at one time or another by Singer.

In the wake of the 1973-74 panic over the world price of food and the concomitant decrease in food aid, numerous other academics and development specialists became interested in food aid reform and attended the 1974 world food conference. It was during this period that Sartaj Aziz, a development reformer who later became Pakistan's agriculture minister, authored a number of relevant proposals for changes in the food aid program. It was also during the 1970s that the literature on food aid and the number of forums for publishing ideas on the subject grew. For example, Food Policy, a journal conceived in 1976, began to carry articles by epistemic community members and even devoted two special issues to the subject of food aid.

By the 1980s, as grain stocks increased, the impetus for reform faded and fewer academic studies on food aid were undertaken. Nevertheless, by this time, a reasonably stable group of specialists from various countries had already formed. Many of these specialists came together in 1983 at the Hague for a seminar on food aid, which was sponsored by the Dutch government and the WFP and addressed virtually all of the major issues. Table 3 lists the participants, many of whom were active community members before the seminar and have remained active since.

While most of the mainstream neoclassical economists viewed food aid as a third-rate and undesirable resource that could only undermine rural agriculture and slowly increase the impoverishment of the poor, the members of the epistemic community continued to defend their view that food aid would work if the underlying principles and practices of the regime were appropriately reformed. Joining Singer in his efforts to ensure that food aid would be reformed rather than abandoned were several other economists, including John Mellor, former chief economist of the Agency for International Aid (AID) and head of the International Food Policy Research Institute (IFPRI); Shlomo Reutlinger, an economist at the World Bank; G. Edward Schuh, former undersecretary of international affairs and commodities for the U.S. Department of Agriculture (USDA) and dean of the Hubert Humphrey Institute of Public Affairs; and Joachim Von Braun, an agricultural economist who studied food aid and economic development for the German government and joined IFPRI in 1985.

22. See Hans Singer, Men Without Work (London: P. S. King \& Son, 1940); Hans Singer, "Distribution of Gains Between Investing and Borrowing Countries," American Economic Review 40 (May 1950), pp. 473-85; and Hans Singer, John Wood, and Tony Jennings, Food Aid: The Challenge and the Opportunity (Oxford: Clarendon Press, 1987). 
TABLE 3. Participants in the 1983 Hague seminar

\begin{tabular}{|c|c|c|}
\hline Name & Country & Affiliation \\
\hline Aseffa Abreha & Ethiopia & Ministry of Agriculture \\
\hline Qazi Kholiquzzaman Ahmad & Bangladesh & Institute of Development Studies, Dhaka \\
\hline Tanwir Ahmad & Pakistan & $\begin{array}{l}\text { Office of the Ambassador to Food Agencies, } \\
\text { Rome }\end{array}$ \\
\hline Maurice Bertrand ${ }^{\mathrm{a}}$ & France & Joint Inspection Unit, United Nations, Geneva \\
\hline Anneliese Binder ${ }^{\mathrm{a}}$ & Switzerland & $\begin{array}{l}\text { Food Security Unit, Food and Agriculture Or- } \\
\text { ganization (FAO) }\end{array}$ \\
\hline Julia Chang Bloch ${ }^{\mathrm{a}}$ & United States & Agency for International Aid (AID) \\
\hline Michael Cracknell & France & $\begin{array}{l}\text { International Federation of Agricultural Pro- } \\
\text { ducers, Paris }\end{array}$ \\
\hline John Crawford & Australia & Australian National University \\
\hline Ruth Dixon & United States & University of California, Davis \\
\hline Saravanamuthu Easparathasan & Sri Lanka & Central Bank of Ceylon \\
\hline Michael N. Gifford & Canada & Directorate of Agriculture, Canada \\
\hline Richard Harley ${ }^{a}$ & United States & $\begin{array}{l}\text { Harvard Institute for International Develop- } \\
\text { ment }\end{array}$ \\
\hline Fabian G. Holder ${ }^{a}$ & Jamaica & World Food Programme, Rome \\
\hline Raymond F. Hopkins ${ }^{\mathrm{a}}$ & United States & Swarthmore College \\
\hline James D. Ingram $^{\mathrm{a}}$ & Australia & World Food Programme, Rome \\
\hline Nural Islam ${ }^{\mathrm{a}}$ & Bangladesh & $\begin{array}{l}\text { Office of Economic and Social Policy, FAO, } \\
\text { Rome }\end{array}$ \\
\hline Philip Johnston $^{\mathrm{a}}$ & United States & $\begin{array}{l}\text { Cooperative for American Relief to Every- } \\
\text { where (CARE), New York }\end{array}$ \\
\hline Richard Jolly & Britain & $\begin{array}{l}\text { United Nations International Children's } \\
\text { Emergency Fund (UNICEF), New York }\end{array}$ \\
\hline Hans J. Kristensen & Denmark & Ministry of Agriculture \\
\hline Jane Kusin & Netherlands & University of Amsterdam \\
\hline John W. Mellor ${ }^{\mathrm{a}}$ & United States & $\begin{array}{l}\text { International Food Policy Research Institute } \\
\text { (IFPRI) }\end{array}$ \\
\hline Larry Minear ${ }^{\mathrm{a}}$ & United States & $\begin{array}{l}\text { Church World Service and Lutheran World } \\
\text { Relief }\end{array}$ \\
\hline Charles Paolillo & United States & World Food Programme, Rome \\
\hline Jean H. Parotte & Britain & International Wheat Council, London \\
\hline Lawrence Pezzullo & United States & Catholic Relief Services \\
\hline Shlomo Reutlinger ${ }^{\mathrm{a}}$ & United States & World Bank \\
\hline G. Edward Schuh ${ }^{\mathrm{a}}$ & United States & University of Minnesota \\
\hline Amartya Sen $^{\mathrm{a}}$ & India & Oxford and Harvard Universities \\
\hline John Shaw ${ }^{a}$ & Britain & World Food Programme, Rome \\
\hline Hans Singer ${ }^{a}$ & Britain & University of Sussex \\
\hline Tarlok Singh & India & Indian Council of World Affairs \\
\hline Jan Sonneveld & Netherlands & $\begin{array}{l}\text { Office of the Dutch Representative to the } \\
\text { FAO, Rome }\end{array}$ \\
\hline Wouter Tims ${ }^{\mathrm{a}}$ & Netherlands & Free University, Amsterdam \\
\hline Tomas Uribe Mosquera $^{a}$ & Colombia & Banco del Estado, Bogota \\
\hline J. J. A. M. Van Gennip & Netherlands & EuronAid, The Hague \\
\hline Francois Van Hoek & Netherlands & $\begin{array}{l}\text { Commission of the European Community, } \\
\text { Brussels }\end{array}$ \\
\hline Brian W. Walker $^{\mathrm{a}}$ & Britain & Oxfam, Oxford \\
\hline Maurice J. Williams $^{\mathrm{a}}$ & United States & World Food Council, Rome \\
\hline
\end{tabular}

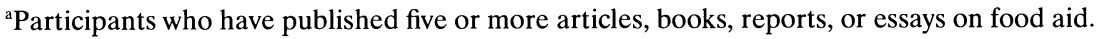


Several other people who were interested in reform at the time of the Hague seminar and have become increasingly active should also be considered members of the epistemic community. Among them are Hannon Ezekiel, who headed the food aid division of IFPRI in the early 1980s; Walter Falcon of Stanford University; Roger Hay, head of the food studies group at Oxford University; Barbara Huddleston, chief of food security at the FAO; Simon Maxwell and Edward Clay, proteges of Singer at Sussex University; Robert Paarlberg of Wellesley College; Hartmut Schneider of the Organization for Economic Cooperation and Development (OECD); Peter Timmer of Harvard University; and Kees Tuinenberg, a Dutch researcher at the WFP and World Bank. $^{23}$

Each of these community members has written articles, proposed reforms in food aid, and consulted with universities or government bodies such as the FAO, WFP, World Bank, and bilateral agencies. While the development experts have their training in a wide variety of disciplines, including economics, other social sciences, and agricultural sciences, they share the same criteria for evaluating the validity of scientific evidence. They read each other's work; meet at workshops several times a year; participate in forums such as the Hunger Exchange, which has been held annually at Brown University since 1988; and work together on advisory boards and in ad hoc working groups, such as the 1978 group that reviewed PL480 and the 1988-89 group that advised the World Bank on food security issues. All of these activities keep the community members in regular face-to-face contact with one another. While they do not necessarily agree on the specific details and the scope of reform to be advocated, they all agree that food aid could and should be used benignly for development, and they all agree on a policy project aimed at the long-term alleviation of hunger. On the basis of this agreement on goals, the epistemic community discussed in this article can be distinguished from another "epistemic community" that also emerged-a more critical, leftist community which advocated abolishing all but emergency food aid and which was strongly influenced by the ideas of Susan George, Tony Jackson, Frances Moore Lappé, and Emma Rothschild. ${ }^{24}$

23. This list excludes a number of contributors to the food aid literature, both in government and in academia, who are debatably members of the epistemic community. For example, Mitchel Wallerstein, now at the National Academy of Science, is the author of an influential volume, Food for War: Food for Peace.

24. For examples of important works written by the radical critics of food aid, see Susan George, How the Other Half Dies: The Real Reason for World Hunger (New York: Penguin Books, 1976); Tony Jackson, Against the Grain: The Dilemma of Project Food Aid (Oxford: Oxfam, 1982); Frances Moore Lappé and Joseph Collins, with Cary Fowler, Food First: Beyond the Myth of Scarcity (Boston: Houghton Mifflin, 1977); and Emma Rothschild, "Is It Time to End Food for Peace?" New York Times Magazine, 13 March 1977, pp. 15-48. In the magazine Food Monitor, which flourished for a decade following the 1974 world food conference, and in a variety of professional and institutional (usually church-related) journals, food aid was also broadly condemned as an insidious and misleading "gift" to the poor. 
At the broadest level, the rationale for giving priority to food security goals rests on a growing consensus among development experts that population growth, food needs, and pressures on the environment are linked. ${ }^{25}$ The nature of the linkages has been a subject of increasing investigation, especially in developing countries where food and population problems dominate "security" concerns. ${ }^{26}$ While each national context presents a particular pattern of relationships and varying degrees of concern for negative external consequences, the scientific community has concluded that a serious global threatone of growing proportion-is arising from the rapid growth of populations in developing countries and the stagnant or declining standards of living faced by those populations. ${ }^{27}$ One consequence of the increase in population and concomitant increase in demands for food is that the developing countries are not only intensifying the use of land for agricultural production but also placing more and more land of marginal value into production. In short, they are pursuing agronomic practices which are not ecologically stable and which cannot provide them with long-term food security. ${ }^{28}$ The most enduring challenges to the four original principles governing food aid have come from this concern.

The principle of using donor surpluses for food aid has been challenged on two counts related to inefficiencies and even negative effects stemming from the practice. On the one hand, relying on surpluses has led to procyclical food aid-that is, recipient countries receiving lower levels of food when they most need it. This exacerbates the problems related to hunger. On the other hand, having permanent surpluses is a bad policy. In the United States during the 1950 s and 1960s, domestic interests did not support the policy of having farmers grow food for food aid, and U.S. officials opposed policies creating permanent surpluses. Indeed, beginning in the 1960s, the United States, Australia, Canada, and some other countries adopted acreage reduction policies to end surpluses. These policies in turn weakened the interests of commodity producers and their legislative representatives in supporting food aid. As U.S. hegemony declined, burden sharing among industrialized states was promoted by the United States and other grain exporters. The creation of the WFP in 1963 and the call for a food aid convention in 1967 were responses to the notion that the rich importing nations of Europe and Japan should also

25. See Bruce F. Johnston and John W. Mellor, "The World Food Equation: Interrelations Between Development, Employment and Food Consumption," Journal of Economic Literature 22 (June 1984), pp. 521-74.

26. The World Bank's Development Report, 1992 (Washington, D.C.: World Bank, forthcoming) seeks to pull together much of the research on the nature of these linkages.

27. See Lester Brown, "State of the World, 1988," paper no. 65, World Watch, Washington, D.C., 1988.

28. For arguments supporting this link, see the contributions in John W. Mellor, ed., "Food Policy, Food Aid and Structural Adjustment Programmes: The Context of Agricultural Development," special issue of Food Policy, vol. 13, February 1988. Many experts have explored this link, as have the leaders of various organizations. For example, Philip Johnson, executive director of the Cooperative for American Relief to Everywhere (CARE), discussed it in his speech in Minneapolis in November 1988. 
support food aid. Concerns about the reliability of food aid provided through disposal of surpluses reached their peak in 1972-74, when U.S. aid fell from 12 million to 3 million metric tons.

Another problem with providing food aid through the surplus disposal principle was the inefficiency involved in resource transfer. The choice of commodities to be transferred was based on the donor's need to dispose of specific surpluses, often bulky ones in particular, rather than on the recipient's need for specific foodstuffs. To counter this, Shlomo Reutlinger, a World Bank economist, proposed the use of an "alpha coefficient." The idea was that the choice of commodities to be involved in a particular project should be based on maximizing the value of the transferred commodity by taking into account both the shipping costs accruing to the donor and the ease with which the people in the recipient country could market the donated commodity and then buy needed household goods from local producers. For example, oil and milk powder were commodities that cost relatively less to ship and were more easily bartered than were bulky grains. Similarly, milk power was less costly for the donor to produce and easier for the recipient to market than were expensive products made from a blend of corn, soy, and milk. Although Reutlinger's proposal caused considerable consternation among producers of highly processed food aid commodities and among some nutritionists, who feared that specialized commodities targeted for women and infants would be neglected, the basic principle of maximizing the value of the resource transfer has become increasingly accepted among food aid specialists. Despite the fact that the principle has not yet been mandated by legislation, it has become widely used in the design of projects by the WFP, AID, the Canadian International Development Agency, and other development organizations. In the mid-1980s, for example, oil was chosen as the commodity to be shipped to Rwanda because it could be easily exchanged on the market and used in support of various activities that would enhance long-term local agricultural production.

The second wave of criticism attacked the principle of additionality. According to this principle, mandated both by legislation and by the creation of a FAO committee to monitor food aid, food provided through this "special" channel (the term used by the International Wheat Council) should be considered an addition to, rather than a substitute for, the recipient's regular commercial imports. As development objectives came increasingly to the fore and as desperately poor recipients, such as those in Bangladesh in 1974, came to be favored, the rationale for additionality weakened. Critics argued that food aid should allow recipient countries to reduce their imports and use the savings to invest in development projects. They also argued that food aid over and above the regular commercial imports had the adverse effect of lowering prices paid to local producers and thereby discouraging them from producing. This criticism, derived from basic supply and demand assumptions, forced food aid managers and supporters to seek devices to prevent the "disincentive" effect. Some have argued, however, that the best solution would be to abandon the additionality principle in favor of a pure substitutability principle, since the 
disincentive effect via its market effect would vanish - a point in which food aid defenders have increasingly taken comfort. ${ }^{29}$

The disincentive criticism, in fact, has been the most frequently debated issue in the epistemic community. Beginning in the 1950s, leading economists, including Theodore Schultz of the University of Chicago (subsequently a Nobel prize winner) and Mordecai Ezekiel of the FAO, argued that using surpluses as food aid was likely to have a negative impact on farmers in recipient countries and would also undercut economic development in those countries. ${ }^{30}$ Two decades later, Susan George, Frances Moore Lappé, Joseph Collins, and other proponents of socialist autarkic development made similar criticisms and concluded that the use of surpluses would harm local producers, undermine local production, distort world efficiency, and deepen the dependency of poor states on the world's capitalist trading systems. ${ }^{31}$ In the 1970 s, this view emerged as the dominant view of the epistemic community.

One solution to the problem was to create a multilateral agency that would be responsible for targeting food aid toward development projects and would thus avoid the criticisms for which bilateral programs were particularly susceptible. In 1960, when Singer was acting as key adviser to Dag Hammarskjold, he had proposed that such an international body be created. This proposal had then come under discussion at the FAO in Rome and had been taken up by George McGovern, who headed the Food for Peace program based in the White House during the Kennedy presidency. In a letter to Eugene Black, then president of the World Bank, Hammarskjold had proposed that the World Bank establish a separate management division to undertake multilateral food aid. At that time, however, mainstream economists viewed food aid as an unreliable, expensive, and distorting form of international transfer and one which the World Bank would be wise not to dirty its hands. Black consequently declined Hammarskjold's proposal. Singer and other members of the epistemic community thus began pushing for an independent multilateral food agency. Among those joining them in promoting this were Frank Shefrin, a senior official in Agriculture Canada, B. R. Sen, an economist who was directorgeneral of the FAO, and McGovern. An international "working group" of the UN agreed on the provisional step of creating the WFP, a multilateral agency to be headquartered in Rome and closely linked with the FAO.

For the development-oriented epistemic community, shifting food aid to a multilateral body was but a first step toward addressing the broad criticisms regarding disincentives. A second step was to target U.S. and European food

29. See Christopher Stevens, Food Aid and the Developing World: Four Case Studies (London: Croom, Helm, 1979); and Singer, Wood, and Jennings, Food Aid.

30. See Theodore W. Schultz, "Value of U.S. Farm Surpluses to Underdeveloped Countries," Journal of Farm Economics 42 (December 1960), pp. 1019-30; and Mordecai Ezekiel, "Apparent Results in Using Surplus Food for Financing Economic Development," Journal of Farm Economics 40 (November 1958), pp. 915-23.

31. See George, How the Other Half Dies; and Lappé and Collins, Food First. 
aid toward countries with large numbers of undernourished people. In the early 1970 s, the U.S. Congress began reconsidering the concessional sales part of U.S. food aid, which had previously been used to support Israel, Portugal, South Vietnam, and other military-political allies. In 1974, the Congress passed legislation requiring that at least 75 percent of the concessional sales be allocated to countries that fell below a specified poverty level. In subsequent years, this level was set as the level at which countries would be eligible for "soft" loans (long-term, low-interest financing) from the World Bank. At the same time, Singer, who had moved to the Institute for Development Studies at Sussex, and several other European academics, especially academics from Germany, began criticizing the EC food aid program for aiding Malta, former French colonies, and other special clients whose income levels were well above that of countries in heavy need. By the mid-1980s, the EC adopted an official policy of targeting the least developed and most food-deficient states, many of which were former British and French colonies.

A third step in shifting the regime principles toward development goals occurred through legislation directed at preventing disincentive effects in recipient countries. In 1979, for example, the U.S. Congress adopted the Bellman amendment to PL480. According to this amendment, the secretary of agriculture was required to certify in each case that giving food aid to a country would not disrupt its markets or act as a disincentive to local production. At about the same time, the WFP Committee on Food Aid Policies and Programs in Rome began to require similar assurances before the WFP would approve food aid to any country.

Thus, by the late 1970 s, the idea that disincentive effects could be and must be prevented had gained the consensus of food aid advocates and critics alike and had become internalized by officials managing the food aid programs in the major donor countries and the WFP. As a result of the institutionalization of this idea, disincentive effects were now hard to find. As noted by Vernon Ruttan, an agricultural economist with extensive experience in international development, "The major impact of the professional literature on food aid has been to narrow the range of controversy about food aid impact. It is difficult for anyone who has limited familiarity with the literature to continue to argue that food aid has a pervasive negative impact on the growth of agricultural production." 32

In addition to criticizing the first two principles of food aid, those of surplus use and additionality, the epistemic community also criticized the third principle, that of short-term commitments based on the economic and political goals of donors. This third principle made food aid unreliable as a resource for multiyear projects and for aid linked to policy reform. This shortcoming was evident, for example, in the case of U.S. aid to India. In the mid-1960s, the

32. Vernon W. Ruttan, "Food Aid: Surplus Disposal, Strategic Assistance, Development Aid and Basic Needs," mimeograph, University of Minnesota, October 1989, p. 60. 
Johnson administration approved the provision of aid to India for only three months at a time. These "short-tether" tactics infuriated the Indians, who needed reliable imports of food during shortages stemming from the lack of monsoon rains during a two-year period ${ }^{33}$ Similar problems encountered by other countries prompted epistemic community members to advocate reform addressing the issues of how long food aid would be available and which countries would be targeted for aid. The results of reforms in response these criticisms are reflected in Table 4, which shows a dramatic change in the pattern of food aid over time. The decline of the politically motivated food aid tied to alliance fidelity with donors is evident in the fact that food aid to Korea and Turkey was drastically cut in the mid-1970s. This decline was accompanied by an increase in allocations to Bangladesh and African nations, which have offered the major donors relatively marginal political and economic assistance. While low-income, food-deficit countries received only about 50 percent of the food aid in the early 1970s, they received nearly 90 percent in the late 1980 s.

Criticism over the fourth principle of food aid-that of directly feeding hungry people- has been the most muted and cautiously worded. Who, after all, would deny food to starving infants? The general thrust of the criticism against delivering food directly to individuals is this: given that the resources available for food aid projects are limited, then the aid must be efficiently used for development ends and not expended for consumption uses, since the latter may even reduce pressure on governments to address rural development and long-term food security goals. ${ }^{34}$ Other than in cases of dire emergency, delivering food directly to the hungry is a suspect principle for several reasons. The costs of transporting food can be excessively high, amounting to 100 to 200 percent of the cost of the food itself in projects involving African countries. ${ }^{35}$ Even if the amount of food in a given aid project is small on a national scale, it can disrupt local food systems. Moreover, sending food for direct distribution to the people may reinforce excessively expensive subsidy programs, as occurred in Egypt and Sri Lanka in the 1970s, or may create administrative nightmares, as was the case in Zaire. ${ }^{36}$

33. See James W. Bjorkman, "Public Law 480 and the Policies of Self-Help and Short Tether: Indo-American Relations, 1965-68," in Report of the Commission on the Organization of the Government for the Conduct of Foreign Policy (Washington, D.C.: Government Printing Office, 1975), appendix 3; and Robert L. Paarlberg, Food Trade and Foreign Policy: India, the Soviet Union and the United States (Ithaca, N.Y.: Cornell University Press, 1985).

34. Johnston and Mellor, "The World Food Equation."

35. Maurice J. Williams, "The African Food Problem and the Role of International Agencies: Report by the Executive Director," World Food Council, Rome, 8 March 1982.

36. See C. Peter Timmer and Matthew Guerreiro, "Food Aid and Development Policy," paper presented at the Agricultural Development Council/Research and Training Network Conference, Colombo, Sri Lanka, August 1980; Joachim Von Braun and Hartwig de Haen, "Impact of Food Price and Subsidy Policies on the Agricultural Sector: Egypt," mimeograph, Ministry of Agriculture of Egypt, USDA and AID, Washington, D.C., July 1982; U.S. General Accounting Office, "Search for Options in the Troubled Food-for-Peace Program in Zaire," mimeograph, Washington, D.C., 22 February 1979; and Murdoch, The Poverty of Nations. 
TABLE 4. Thousands of metric tons of cereal allocated to major food aid recipients, 1966-67 through 1990-91

\begin{tabular}{|c|c|c|c|c|c|c|}
\hline Recipient & $1966-67$ & $1970-71$ & $1975-76$ & $1980-81$ & $1985-86$ & $1990-91$ \\
\hline \multicolumn{7}{|l|}{ Africa } \\
\hline Angola & - & - & 6.0 & 24.8 & 52.5 & 156.7 \\
\hline Ethiopia & 3.0 & 3.4 & 86.6 & 228.0 & 799.2 & 911.6 \\
\hline Ghana & 20.9 & 97.7 & 32.0 & 94.3 & 96.4 & 89.2 \\
\hline Kenya & 2.6 & 2.5 & 8.7 & 172.9 & 139.4 & 108.1 \\
\hline Malawi & 0.1 & 0.5 & 0.2 & 16.6 & 5.1 & 251.8 \\
\hline Mozambique & - & - & 57.5 & 154.6 & 261.7 & 669.4 \\
\hline Senegal & 24.0 & 15.8 & 16.1 & 152.7 & 117.5 & 34.5 \\
\hline Somalia & 0.5 & 2.3 & 55.1 & 330.1 & 142.9 & 130.3 \\
\hline Sudan & 0.1 & 28.0 & 24.8 & 194.5 & 939.1 & 403.5 \\
\hline Tanzania & 7.9 & 8.8 & 108.7 & 235.8 & 65.8 & 16.0 \\
\hline Zaire & - & 16.7 & 19.9 & 77.0 & 101.0 & 102.1 \\
\hline Zambia & - & 0.2 & 5.3 & 84.4 & 84.6 & 6.0 \\
\hline \multicolumn{7}{|l|}{ Asia } \\
\hline Bangladesh & - & 610.0 & $1,186.9$ & 736.9 & $1,300.3$ & $1,137.5$ \\
\hline China & 5.2 & - & - & 37.0 & 290.2 & 148.0 \\
\hline India & $1,169.2$ & $2,384.2$ & $1,107.8$ & 435.3 & 257.4 & 468.3 \\
\hline Indonesia & 13.8 & $1,154.5$ & 136.5 & 381.7 & 50.2 & 79.4 \\
\hline Kampuchea & 17.7 & 10.6 & - & 133.0 & 34.3 & 11.2 \\
\hline Korea & 22.2 & $1,882.0$ & 344.2 & 678.2 & - & - \\
\hline Pakistan & 95.6 & $1,004.0$ & 788.9 & 276.8 & 383.8 & 102.2 \\
\hline Philippines & 18.2 & 42.5 & 61.9 & 84.6 & 181.0 & 213.6 \\
\hline Sri Lanka & 14.6 & 215.6 & 129.1 & 226.2 & 365.5 & 283.8 \\
\hline Vietnam & 1.6 & 631.5 & 32.9 & 150.4 & 16.7 & 105.2 \\
\hline \multicolumn{7}{|l|}{ Latin America } \\
\hline Bolivia & 3.7 & 8.5 & 8.0 & 54.7 & 292.5 & 304.8 \\
\hline Brazil & 60.1 & 433.8 & 3.0 & 3.0 & 5.5 & 9.7 \\
\hline Chile & 20.1 & 19.1 & 351.3 & 21.3 & 10.3 & 10.9 \\
\hline Colombia & 22.9 & 143.5 & 26.0 & 5.4 & 5.7 & 100.3 \\
\hline El Salvador & 7.1 & 4.7 & 4.0 & 49.5 & 278.1 & 168.1 \\
\hline Honduras & 2.5 & 2.0 & 13.4 & 35.8 & 135.0 & 177.9 \\
\hline Jamaica & 4.0 & 5.7 & 6.4 & 37.2 & 202.5 & 222.1 \\
\hline Mexico & - & - & - & - & 10.8 & 350.0 \\
\hline Nicaragua & 2.0 & 0.9 & 3.1 & 58.3 & 40.6 & 98.3 \\
\hline Peru & 8.6 & 118.0 & 28.7 & 115.9 & 180.2 & 308.2 \\
\hline \multicolumn{7}{|l|}{ Middle East } \\
\hline Algeria & 104.8 & 158.3 & 16.3 & 28.5 & 3.6 & 57.2 \\
\hline Egypt & 56.7 & 253.7 & $1,085.5$ & $1,864.9$ & $1,798.7$ & $1,263.3$ \\
\hline Israel & 2.6 & 807.2 & 98.1 & 9.8 & 8.4 & 40.5 \\
\hline Morocco & 53.6 & 334.5 & 37.1 & 120.4 & 142.3 & 306.1 \\
\hline Tunisia & 13.3 & 254.3 & 60.8 & 98.8 & 79.7 & 445.8 \\
\hline Turkey & 18.5 & 757.7 & 7.0 & 9.1 & 5.7 & 2.8 \\
\hline
\end{tabular}

${ }^{\mathrm{a}}$ Dash $=$ none or negligible.

Sources. Food and Agriculture Organization (FAO), Food Aid in Figures (Rome: FAO, 1983, 1985, 1989, and April 1991); U.S. Department of Agriculture (USDA), Economic Research Service, Annual Report on PL480 (Washington, D.C.: Government Printing Office, 1966); and Food Aid Centre, Canadian Industrial Development Agency, mimeograph, Ottawa, 1984. 
The research by Roger Hay of Oxford University and Simon Maxwell of Sussex University underscores the difficulties that direct delivery of food presents. ${ }^{37}$ In many cases, refugees have been provided free food while people who are equally poor and live in nearby locales have been forced to pay for it. In other cases, existing work projects using food as an incentive or payment have been forced to compete with refugee camps providing free food. Once a program involving the direct delivery of food has been established, it is difficult to "wean" people from it. As a result of these findings, a concerted effort was made to allow the food provided by food aid programs to be sold whenever possible. The rationale was not to make desperate people even more desperate but, rather, to create equity and a sense of quid pro quo for recipients and to blend the emergency intervention into a longer-term framework for economic development within the recipient country.

The older regime principles, still imbedded in parts of U.S. legislation, sometimes have made it difficult to follow goals based on this newer rationale. This occurred, for example, in the case of food being sent from the United States under the auspices of a voluntary organization, the Cooperative for American Relief to Everywhere (CARE), to the Diradawa region of Ethiopia. In 1987, CARE officials in Ethiopia felt that the recipients of the emergency food supplies were ready to be moved toward a program that would exchange labor for food and might eventually return the people to their homes with some resources and thereby allow them to resume their previous occupations, which largely centered on farming. To accomplish this transition, CARE was forced to turn to the EC for food aid, since U.S. legislation prevented the "emergency" supplies to be used in a "sales" manner. Food aid experts in Ethiopia and elsewhere have applauded the idea of food-for-work as a transition from emergencies and have applied it in a number of cases. Indeed, reports of these cases have circulated widely among the development agencies and officials responsible for food aid transfers.

Epistemic community members have raised other questions regarding the role of the fourth principle. It presumes, as an allocation rationale, that feeding the hungry is an end goal. Then should not allocations be based on the recipients' nutritional needs rather than on the donors' diplomatic or market development goals? The principles of surplus disposal and additionality were linked with trade-based motivations, as discussed earlier, and these motivations were not always consistent with giving top priority to the food needs of recipients. Thus, in the late 1970s and early 1980s, the FAO, IFPRI, and other organizations began to analyze the food needs of various recipients. In their studies, they assessed not only the recipients' transitory and short-term needs, such as those arising from crop failures in a particular year, but also their

37. See Roger W. Hay, "Criteria for the Provision of Emergency Food Aid," document CFA/21/10, addition 1, WFP, Rome, March 1986; and Simon Maxwell, "European Food Aid: Not Just for Emergencies," in CAP Briefing (Brussels), nos. 1-3, October 1987. 
persistent and long-term "structural" needs, such as those linked with chronic and widespread nutritional deficiencies. Beginning in 1981, pursuant to congressional urging, the Economic Research Service of the USDA also began to compile assessments of food needs and publish them regularly in their World Food Needs and Availabilities. As a result of these studies, the nutrition-based needs of recipients have gained salience in the allocation decisions of most donors. ${ }^{38}$

While the overall trend in recent years has been to shift allocations of food aid toward food-insecure countries, the distribution of food aid nevertheless remains skewed. Moreover, the volume of food distributed remains well below the absolute needs of recipients. To illustrate these points, Table 5 shows the actual allocation of food aid to selected countries in 1988-89 and compares it with an alternative allocation based on nutritional needs. If the distribution of food aid had been based solely on the nutritional needs of the recipients, rather than being based in part on the political and other motivations of the donors, then less of the allotted ten million metric tons of cereal would have gone to Latin America and the Middle East and far more would have gone to Africa and Asia. ${ }^{39}$ In short, if food security were the top priority, more food would be channeled to the countries with the greatest nutritional needs, countries whose food insecurity is often linked with declining agricultural productivity, increasing deforestation, and high population growth.

The criticisms outlined in this section have for the most part emanated from the epistemic community and have given rise to an evolutionary change in the food aid regime. New principles, which largely contradict the founding ones and which reflect market efficiency and development goals rather than exceptionalism and diplomatic gains, have emerged. According to these new principles, food aid (1) should be supplied in the most efficient manner possible, (2) should be a substitute for the usual commercial food imports in recipient countries, (3) should be given under long-term commitments, and (4) should serve as the basis for the recipients' economic development aimed at addressing long-term food security problems, rather than merely serving as a vehicle to alleviate immediate food shortages.

In recent decades, these new principles have become embedded in the institutional practices of multilateral agencies, particularly the WFP, and of bilateral agencies as well. In some cases, such as that involving the supply of

38. See National Research Council, Food Aid Projections for the Decade of the 1990s. While academic-congressional coalitions in the United States pushed for the recognition of the nutrition-based needs of recipients and had a strong impact on the allocation decisions made by policymakers, the Black Caucus and other special interest groups did relatively little lobbying and cannot be credited with bringing about reform in the process of allocating aid. Even during the 1984-85 food shortages in Africa, Americans of African origin played no special role in mobilizing support.

39. See Raymond F. Hopkins, "Increasing Food Aid: Prospects for the 1990s," Food Policy 15 (August 1990), pp. 319-27. 
TABLE 5. Thousands of metric tons of cereal imported by and allocated to selected food-insecure countries, 1988-89: a comparison of the actual pattern of food aid $(F A)$ allocation and an alternative pattern based on nutritional estimates of need $^{\mathrm{a}}$

\begin{tabular}{|c|c|c|c|c|c|}
\hline Recipient & $\begin{array}{c}\text { Total } \\
\text { imports }\end{array}$ & $\begin{array}{c}\text { FA as a } \\
\text { percentage } \\
\text { of imports }\end{array}$ & $\begin{array}{c}\text { Actual } \\
\text { FA } \\
\text { allocation }\end{array}$ & $\begin{array}{c}\text { Alternative } F A \\
\text { allocation } \\
\text { for need }^{\mathrm{b}}\end{array}$ & Changes \\
\hline Sub-Saharan Africa & 7,513 & 40 & 3,011 & 3,844 & +833 \\
\hline Angola & 319 & 36 & 116 & 107 & -9 \\
\hline Ethiopia & 452 & 100 & 452 & 950 & +498 \\
\hline Ghana & 211 & 42 & 88 & 127 & +39 \\
\hline Kenya & 295 & 42 & 123 & 398 & +275 \\
\hline Mozambique & 506 & 100 & 506 & 551 & +45 \\
\hline Senegal & 626 & 11 & 67 & 57 & -10 \\
\hline Somalia & 246 & 72 & 176 & 135 & -41 \\
\hline Sudan & 609 & 67 & 410 & 187 & -223 \\
\hline Zaire & 378 & 34 & 127 & 127 & - \\
\hline Zambia & 139 & 81 & 112 & 78 & -34 \\
\hline Middle East & 10,197 & 15 & 1,488 & 775 & -713 \\
\hline Egypt & 8,730 & 14 & 1,192 & 536 & -656 \\
\hline Morocco & 1,467 & 20 & 295 & - & -295 \\
\hline Asia & 28,595 & 11 & 3,176 & 4,464 & $+1,288$ \\
\hline Bangladesh & 2,138 & 63 & 1,356 & 1,598 & +242 \\
\hline China & 15,973 & 1 & 235 & - & - \\
\hline India & 2,627 & 12 & 322 & 1,692 & $+1,370$ \\
\hline Indonesia & 1,570 & 12 & 182 & - & -182 \\
\hline Philippines & 1,337 & 23 & 307 & 144 & -163 \\
\hline Sri Lanka & 1,186 & 23 & 278 & 264 & -14 \\
\hline Vietnam & 425 & 27 & 114 & - & - \\
\hline Latin America & 1,842 & 76 & 1,391 & 837 & -554 \\
\hline Bolivia & 253 & 58 & 147 & 175 & +28 \\
\hline Dominican Republic & 632 & 55 & 349 & 85 & -264 \\
\hline El Salvador & 214 & 100 & 214 & 70 & -144 \\
\hline Honduras & 201 & 77 & 154 & 96 & -58 \\
\hline Nicaragua & 151 & 100 & 151 & 11 & -140 \\
\hline Others & 249 & na & 978 & 124 & +124 \\
\hline $\begin{array}{l}\text { Total, low-income, food- } \\
\text { insecure states }\end{array}$ & 48,396 & 19 & 9,066 & 10,044 & +978 \\
\hline $\begin{array}{l}\text { Total world figures, develop- } \\
\text { ing countries }\end{array}$ & 117,000 & 9 & 10,044 & 10,044 & 0 \\
\hline
\end{tabular}

${ }^{a}$ Food-insecure countries encompassed here are designated in the Food and Agriculture Organization (FAO) terminology as "low-income, food-deficit countries." Dash = none or negligible; na $=$ data not available.

${ }^{\mathrm{b}}$ The alternative FA volumes were calculated using figures from the U.S. Department of Agriculture (USDA), World Food Needs and Availabilities (Washington, D.C.: Government Printing Office, Winter 1989), p. 4. The figures assume an identical amount of total aid $(10,044)$ but reallocated according to the nutrition-based estimates done of "assessed additional cereal needs" by the USDA Economic Research Service.

Source. FAO, Commodities and Trade Division, Food Outlook (Rome: FAO, February 1990), pp. 2 and 39-40. 
nonsurplus food, specific new practices have evolved but have not received much publicity. This was true, for example, of the new practice of making "triangular" transactions, with food for a recipient country purchased from producers in neighboring countries. In other cases, as with the case of long-term commitments, a new principle has been publicly advocated by food aid specialists based on expert consensus but has met with resistance from national government budgetary authorities, diplomats, or commodity lobbyists. Nevertheless, once shifts in food aid practices and principles have occurred, they have been largely irreversible.

While the shifts in practices and principles took place most rapidly after the panic over food shortages in the early 1970s, their impact continued to be felt even when world surpluses grew in the following years. In spite of pressures to lower surpluses in the United States, Canada, and European countries in the 1980s, for example, regression equations indicate that food aid practices were less motivated by the goal of disposing surpluses than they had been in earlier periods ${ }^{40}$ Although surpluses have declined since 1988 and the general direction of liberalizing domestic trade policies is likely to continue with prodding from the General Agreement on Tariffs and Trade (GATT), all trading countries negotiating surplus reductions in the GATT forum now agree that food aid should be delinked from trade promotion. ${ }^{41}$

Some shifts in principles have been accompanied and facilitated by the growth in the number of food aid donors. When Germany, Japan, and other countries that were not food exporters became donors of food aid in the 1970s, the food-exporting countries that were already donors felt less pressure to continue the practice of surplus disposal, a practice that was no longer efficient and was soon to be replaced by explicit export subsidy programs. While countries such as India, Thailand, and Zimbabwe were clearly too poor to donate food to neighboring countries in need, they could be involved in the food aid program through triangular transactions. For example, one African country could be paid by Japan, Germany, or another rich nation to supply food to a nearby African country targeted for aid. Triangular aid programs of this type can be extremely helpful, as development specialists have noted, ${ }^{42}$ since they provide cash to and encourage development in the country producing the food, they strengthen regional markets, and they deliver food at a lower transport cost to the designated recipient. Even the United States, the premier food-exporting nation, has entered into triangular supply arrangements,

40. Shahla Shapouri and Margaret Missiaen, "Food Aid: Motivation and Allocation Criteria," Foreign Agricultural Economic Report no. 240, USDA Economic Research Service, Washington, D.C., February 1990, pp. 18-22.

41. Even the U.S. representatives involved in the GATT negotiations have expressed their concern and argued that only "bona fide" food aid should be allowed under a GATT agreement.

42. See, for example, Edward Clay, "Triangular Transactions," mimeograph, WFP, Rome, 1987; and D. John Shaw, "Triangular Transactions in Food Aid: Concept and Practice-The Example of the Zimbabwe Operations," IDA Bulletin (bulletin of the Institute of Development Studies, University of Sussex), vol. 14, April 1983, pp. 29-31. 
shipping wheat to Zimbabwe so that Zimbabwe could in turn supply white maize to Zambia as food aid.

In general, as food aid has become a smaller part of world grain trade, concerns about its market-distorting effects have also declined. The practice of substituting food aid for commercial imports is now viewed as a logical means to offset market disincentive effects and is also widely upheld whenever food aid is justified as a means to support the balance of payments in recipient countries. In such cases, the conflict between the principle of substitutability and that of additionality is largely ignored. As a result, the FAO Committee on Surplus Disposal, which was created in 1954 to ensure that food aid would not displace commercial sales, has for the most part become superfluous. Nevertheless, as long as both principles exist as legitimating forces within the food aid regime, efforts will continue to be made to satisfy one or the other, or, occasionally and inconsistently, both.

As the economic development of recipient countries gained priority, food aid specialists recommended that a multiyear approach be adopted as a way to lend greater stability to development undertakings and to make food aid more readily integrated with financial aid. The importance of such integration was in fact emphasized by the World Bank in a report coauthored with the WFP. ${ }^{43}$ Indeed, the World Bank has begun efforts to develop a framework for cofinancing among donors, with some providing cash and others providing food resources for longer-term development projects. Japan and other significant donors that are not food exporters have shown their willingness to become involved in financing projects when these projects are not competitive with their own domestic industries. ${ }^{44}$ Similarly, in the United States, Canada, and the EC, budgeting and planning processes have begun to reinforce the tendency to integrate food aid with regular financial aid flows. While budget officials have opposed formally committing their governments to food aid for more than a year at a time, their budgets for foreign aid now combine cash and food resources over a several-year planning horizon.

The principles that the epistemic community of scholars and practitioners have worked out since the 1960s also stress four factors that have an impact on the outcome of providing food aid. First, whether or not food aid is a substitute for or an addition to domestic production, policies affecting investment and efficiency in food production will have an impact on disincentive effects. If disincentives can be avoided, this in turn will lessen future needs. Second, macroeconomic and food sector policies affecting prices and incentives are important in the allocation of food aid, since the aid can reinforce or undercut these policies. Third, future food availability and future production will be affected less by market-driven prices than by the targeted or general food subsidies and the cost effectiveness of such subsidies offered by recipient 
governments. And, fourth, the nutritional and health-related needs of specific recipients will be affected by the choice of commodities provided as food aid and the efficiency of resource transfer strategies. Choosing commodities on the basis of recipient needs and efficient transfer, rather than on the basis of donor needs to dispose of surplus commodities, such as dates from Saudi Arabia or fish from Norway, will have a more positive impact on recipient countries and will reduce their future needs for food aid.

\section{Four historical case episodes}

In this section, I review four episodes of reform in the food aid regime, each concerning an issue discussed briefly above: the issues of disincentives, the efficiency of resource transfers, the criteria for allocation, and the conditionality of food aid. In tracing the origins of reform in these areas, I begin in 1958, when the Senate committee headed by Hubert Humphrey held hearings on the idea of changing PL480 into a "food-for-peace program." I focus in particular on the ways in which the new information that was generated and disseminated by members of the food aid epistemic community helped bring about reforms.

In each of the "cases" discussed here, reforms of existing food aid practices occurred incrementally and with occasional setbacks. It was generally during periods when narrow interest-based forces were receding that epistemic community members encountered success in their efforts to shift the specific rules and practices of the regime in a direction that would accomplish their goal of enhancing global equity through development in the poorest states and thereby maximizing global economic development. The members of the community were not oblivious to the domestic political factors that provided donor countries with an incentive or rationale for supporting food aid programs, perhaps even increasing the amount of aid that would otherwise have been available to recipients. Consequently, the main concern of the community was not to enlarge food aid budgets but, rather, to distribute the available food aid efficiently and wisely and with humanitarian concerns in mind.

\section{Disincentives}

The disincentives argument set forth by Mordecai Ezekiel in 1958 and Theodore Schultz in 1960 created a skepticism about food aid that has lingered for years. ${ }^{45}$ According to this argument, because demand is less elastic in developing countries that in developed countries, even a small change in the 
supply of food to developing countries could cause food prices to fall substantially, thereby reducing the incentive of local producers to continue their agricultural production. Domestic production might even decline to the point at which the total amount of food (the volume of aid shipments plus domestic products) would be less than if no food aid were given. This argument was frequently incorporated in introductory economic courses not only in the United States and other developed countries but throughout the world. As a result, thousands of academics became saturated with the argument in its primitive form.

In the wake of criticisms stemming from this argument, over twenty-five empirical studies on possible disincentive effects were undertaken, many of them focusing on India, which was the largest recipient of food aid in the $1960 \mathrm{~s} .{ }^{46}$ The results of these studies and the continued dialogue among food aid specialists led to a substantial revision in the assumptions and analysis of the disincentive effect, as noted by Vernon Ruttan, a member of the epistemic community: "Professional dialogue over the costs and the impact of food aid in the 1950s and early 1960s was heavily conditioned by the disposal orientation of the food assistance programs. A good deal of effort went into attempts to test the disincentive hypothesis, with largely inconclusive results.... By the mid-1970s, the evidence that had been assembled was being interpreted to imply that under conditions of food scarcity or effective program management the direct disincentive effects on agricultural production could be quite small." ${ }^{47}$

As members of the epistemic community pointed out, the disincentive effects would be overcome if the food aid were provided in a manner that generated increased effective demand on the part of the people in recipient countries. They also noted that in Egypt, Sri Lanka, and other countries with substantial subsidization programs, free market price variation was largely eliminated by government policy. Where governments rather than markets set prices, the disincentive argument would be largely irrelevant. However, the most important solution to the disincentive problem, according to the epistemic community, was to change the regime principle of additionality. If countries that were pressed to import food to meet the basic nutritional needs of their people were allowed to substitute food aid for imports, the disincentive effect would not occur.

Eliminating the additionality principle, however, has been difficult. Exporting states have had a strong interest in expanding foreign markets, and their producers have not wanted their food to be donated indefinitely to overseas countries. Members of the epistemic community have argued that if food aid were to be focused on poor countries in need and if it were to be used as a

46. These empirical studies were reviewed by Paul J. Isenman and Hans W. Singer in "Food Aid: Disincentive Effects and Their Policy Implications," Economic Development and Cultural Change 25.(January 1977), pp. 205-37.

47. Ruttan, "Food Aid," pp. 55-56. 
substitute for commercial imports, this would allow the recipients to invest in development projects, and the resulting economic growth would in turn make the recipients more likely customers for imports in the future. In the 1950s and 1960s, agricultural officials and trade representatives of farm commodity groups gave little weight to this argument. Trade-oriented groups in a number of countries, including Argentina, Australia, and Canada, were particularly critical of the U.S. food aid program. Complaining that the U.S. program undercut their potential commercial markets by creating or distorting international markets, these countries brought their cases before the FAO Committee on Surplus Disposal (CSD). The CSD worked out an elaborate set of rules for reviewing food aid proposals, all of which were to receive the imprimatur of the CSD before the food was actually shipped. Since agriculture was largely untouched by the GATT rules, the CSD and the International Wheat Council served as the two major international forums in which the trade-distorting aspects of food aid could be criticized by food-exporting countries.

In the 1970s, a new approach to resolving the disincentive program arose. The approach was greatly facilitated by the fact that food prices in 1973-74 had risen sharply and the amount of food aid from the United States had dropped from about 10 million to 3 million metric tons while the total food aid from all donors had fallen from 12 million to 8 million metric tons. In this period, when Bangladesh was desperately short of cash and famine threatened the lives of an estimated one million people there, adherence to the additionality principle seemed onerous, irrelevant, and even perverse. Consequently, since the mid-1970s, the number of food aid proposals questioned by the CSD has dropped. The few cases that have been questioned have tended to involve disputes between the United States and Canada over dairy commodities to be provided to South American countries. Although the CSD continues to meet every two weeks in Washington, it deals with few issues of any substance. If the Uruguay Round eventually succeeds in bringing agriculture under GATT disciplines, the remaining activities of the CSD may be transferred to GATT, in which case GATT would substitute its own legal procedures to ensure that food aid in the 1990s and beyond does not become a disguised form of export subsidies used to avoid the commitment to agricultural liberalization.

While the regime has not formally abandoned the principle of additionality, this principle is now rarely enforced. Moreover, as noted earlier, measures to avoid the disincentive effect are now required by the WFP and mandated in U.S. legislation through the 1979 Bellman amendment to PL480. These specific changes have been accompanied by general changes in the attitudes of development economists and agencies toward food aid as a resource for use in development activities. The turnaround of the earlier attitude of the World Bank is noteworthy. For example, in the case of sub-Saharan Africa, the one region where per capita food production has declined since 1970, the World Bank concluded in the 1980s that few countries could afford to pay for the food imports they needed and that food aid would be an effective solution to their 
shortages. Indeed, as a result of declining per capita production as well as periodic droughts, food aid to the region expanded from 2 percent of the total world food aid in 1970 to between 35 and 40 percent of the total in 1985-90. ${ }^{48}$

Although additionality has been largely eliminated in practice, its shadowy persistence is an important testimony to the continuing influence of commodity interests and farm groups, especially in the United States. The Department of Agriculture members of the U.S. interagency committee overseeing food aid continue to press for additionality, in spite of the Bellman amendment's emphasis on avoiding disincentives. In addition, other donor governmentsparticularly Australia, Canada, New Zealand, and other food-exporting members of the Cairns Group involved in the GATT negotiations-continue to fear that the United States, the EC, or both will use food aid as a mechanism to dump surplus commodities and to steal markets. This fear has been fueled by the fact that in the mid-1980s, the United States and other food-exporting countries held extraordinarily large stockpiles, larger in absolute size than in any previous period. Consequently, the suggestion that the CSD be disbanded has been rejected, and the additionality principle remains "on the books." Much like the "blue laws," which still prohibit supermarkets from opening on Sundays in some American states, the additionality principle has the potential for disrupting widely adopted practices. Nevertheless, the current practice of maximizing the extent to which food aid can go to recipient countries as a substitute for their commercial imports is unlikely to be challenged on the basis of arguments concerning unfair trade practices. This is because the allocation of food aid has shifted away from countries such as Brazil, Korea, and Turkey, where the potential for medium-term commercial market development was great, and has concomitantly shifted toward the world's most impoverished countries, where this potential is practically nil. By 1989, Egypt was the only major commercial importing state that remained a significant food aid recipient. Recognizing this, domestic export interest groups have adopted a more permissive attitude toward substitutability. Although they have blocked the formal removal of the additionality principle, they have no compelling reason or resources to demand a return to its actual implementation.

\section{The efficiency of resource transfers}

Food aid has been criticized for being doubly tied. On the basis of the original regime principles, it has been tied to commodities from donor states and also to a particular type of commodity-namely, food..$^{49}$ Economists and development aid administrators have found food aid particularly distasteful

48. See Raymond F. Hopkins, "Food Aid: Solution, Palliative, or Danger for Africa's Food Crisis?" in Stephen K. Commins, Michael F. Lofchie, and Rhys Payne, eds., Africa's Agrarian Crisis: The Roots of Famine (Boulder, Colo.: Lynne Rienner, 1986), p. 207.

49. During the $1950 \mathrm{~s}$ and $1960 \mathrm{~s}$, tobacco, cotton, and similar agricultural products were regularly included under the category of "food" provided as food aid, at least in the U.S. program. 
because it seemed too management-intensive and carried heavy transportation costs. Tony Jackson, for example, argued that in virtually no project was the providing of food as efficient as providing cash. ${ }^{50}$ The stipulation that aid be given in the form of food was one reason why World Bank officials were leery of accepting responsibility for multilateral flows of food aid in 1960 .

Singer, who became the most cogent proponent of the counterargument to this viewpoint, pointed out that all aid is tied. A country receiving cash, for example, can do nothing useful with it until it turns the cash into the imports required by some element in the country, whether it be machinery for industrialization or Mercedes Benz imports for the use of officials. Bringing in such commodities also carries shipping costs. Moreover, since both the use of the cash and the shipping arrangements are often less regulated, the opportunities for corruption are greater if cash rather than food is provided. ${ }^{51}$ This argument has gained increasing weight and has been regularly cited in documents and reports issued by the World Bank, the WFP, and AID.

The epistemic community members have acknowledged that giving aid in the form of food can be inefficient. Their point is, however, that other aid may be equally inefficient. In the case of food aid, they have recommended two avenues for reducing the inefficiency: flexibility and monetization. In the first instance, the idea is that the choice of commodities shipped to a particular country should be altered on the basis of the changing needs of that country. For example, when a drought in Niger devastated the country's millet harvest in 1984-85, shipments of large volumes of cereal were scheduled. But by 1985-86, Niger had a substantial rebound in its millet crops and needed nongrain aid, particularly milk, since the drought had also reduced the number of cattle and thereby caused a milk shortage. The inability to respond by switching to other commodities in this and similar cases has been attributable to the efforts of specific commodity interests to "lock in" particular flows as well as to bureaucratic inertia. Bureaucrats within development agencies have often failed to understand food markets in countries targeted for aid, and even the officials within the recipient countries have sometimes acted in ignorance.

Nevertheless, within the last two decades, the extent to which initial commodities have been switched from time to time to meet the changing needs of recipient countries has expanded greatly, and other arrangements have also been made to improve the efficiency of food aid. Perhaps most notable among these changes has been the willingness of donors to use trilateral and triangular transactions. In a trilateral transaction concerning white maize, for example, the United States, which grows white maize but does not export it, might provide wheat to Kenya, a country that would otherwise import wheat commercially, with the understanding that Kenya would then export its white maize to a designated recipient, such as Sudan or Zambia. In contrast, a 
triangular transaction would involve cash from a donor country to purchase food from a second country or region for use in a third. For example, Japan might purchase commodities in Thailand for use as food aid elsewhere. Indeed, donor purchases might even be "local." The UN might buy food in southern Ethiopia to supply needy populations in northern Ethiopia. In both instances of LDC purchases, improved efficiencies of the transaction would be aimed at maximizing the amount of aid received by the recipient.

Another major mechanism for maximizing the resource transfer value of food aid is monetization - that is, shipping food to recipient countries so that it can be sold in the local markets-a practice strongly advocated by Shlomo Reutlinger and other members of the epistemic community. Ideally, the food aid would be provided in a commodity that is already in short local supply, such as wheat, rice, or oil. The amount provided would not exceed the amount of local unmet demand, and the food would be sold on the local market at a price not lower than that of commercial imports. The currency raised through the sales of food could then be used to buy local commodities, such as cassava, plantain, sorghum, and millet, which can in turn be used in school feeding projects oriented toward nutritional goals or in food-for-work projects involving the building of dams, roads, and irrigation systems. Alternatively, the local currency could be used to target employment opportunities for poor people and pay them fully in cash. By stimulating local food sales, monetization of food aid has the potential of raising the incentive for production of local commodities, and it allows local transportation and handling costs to be minimized.

Since the 1970s and 1980s, under the auspices of the WFP and other food aid programs, the practice of monetization has been increasing, as has the practice of swapping commodities. In a swap arrangement involving wheat, for example, the commodity is delivered in a port city to a wholesale enterprise, and in exchange for this commodity the ministry of health or other implementing agency then receives equal or greater volumes of local food commodities for use in mother-child health clinics or other projects.

Although most recipient governments like the idea of monetization, it is opposed by some voluntary agencies which fear that the practice will undercut their role as food managers, that the benefits to the poor may be diverted, or that having to sell a commodity before nutritional and developmental projects can be implemented will entail added bureaucratic burdens. Commercial interests also fear that monetization will further weaken the additionality principle discussed above. Moreover, the practice remains under debate, since nutritionists are greatly troubled by the probable elimination of shipments of commodities such as corn-soy-milk and other high-cost blended foods. ${ }^{52}$ Some

52. On the subject of monetization, see National Academy of Science, National Research Council, Nutritional Aspects of Public Law 480, Title II Commodities (Washington, D.C.: National Academy Press, 1982). For a discussion of the National Academy's report, see Shlomo Reutlinger and Judit Katona-Apte, "The Nutritional Impact of Food Aid," Nutrition Today 19 (May-June 1984), pp. 1-10. 
opponents have formed a narrow food aid coalition with shipping interests and with the U.S. blended food industry, represented in particular by a half dozen firms that provide such specialized food aid commodities as corn-soy-milk and are based largely in the Kansas City area.

Perhaps the largest obstacle to the practice of monetization is the widespread idea that directly providing free food to the poor is the best approach to food aid. The image of dusty refugee camps in which malnourished children receive handouts of American grain from sacks containing a U.S. logo-an image that links a national symbol to the alleviation of near-starvation of endangered populations-is indeed compelling to many U.S. congressional members involved in decision making regarding PL480 legislation (which still provides over half of the volume of world food aid) as well as to their constituents. On the one hand, in extreme cases, perhaps involving 10 percent of food aid, the direct provision of food through airlifts or convoys is justified, as in the cases of Jordan, Ethiopia, Liberia, and Sudan in 1990. On the other hand, for about 90 percent of the world's food aid, this imagery is inappropriate and serves to promote an inefficient use of the aid.

Recognizing the importance of implementing practices that maximize the resource transfer value of food aid, in the 1980s the EC adopted the policy of allowing up to 10 percent of its food aid budget to be awarded in cash rather than commodities, with the cash to be allocated to recipients during periods of substantial rises in their local food production. In the United States, the recommendation to monetize grant aid was built into PL480 legislation in the 1980 s, and the authority to pursue this practice was expanded in the 1990 U.S. farm bill. Moreover, the use of swap arrangements by the WFP and other donors has grown substantially since the early 1980s. These results were in keeping with the advice given by food aid specialists and reflect their work with the staff and members of the EC Parliament and U.S. Congress. A similar impact of the ideas of the specialists is evident in other donor states, including Japan, which now increasingly provides its food aid through triangular transactions and with a view toward efficiency as well as diplomacy. The shift toward an efficiency principle advocated by food aid reformers has thus made major progress and is reflected in the fact that the proportion of food aid that is monetized or swapped has gone from practically zero in the 1950 s to over 50 percent in the 1990 s. $^{53}$

\section{The criteria for the allocation of food aid}

There have been two substantial shifts in the targeting of food aid to recipient countries. In the early period of food aid, Britain, Germany, Japan, and other countries that are now donors had been recipients. From the 1950s to 
the early 1970s, the aid shifted to countries of the Middle East and Asia, such as Iran and India. Nevertheless, China, which would seem a natural recipient for food aid because of its large population and low nutrition levels, was excluded for Cold War reasons until the 1980s (see Table 4). Beginning in the 1970s, a second shift occurred toward the poorest of the developing countries, most of which were in Africa. This shift meant that countries with a clear potential for commercial exports were increasingly delinked from food aid. Diplomatic and trade rationales for the establishment of food aid were thus attenuated. One major step in this regard was the U.S. rule that was passed by Congress in 1974 and refined in 1975. According to this rule, as noted above, the United States could not provide more than 25 percent of its concessionally sold food aid to countries whose incomes were above the level of countries eligible for soft loans from the World Bank. This level in terms of gross national product per capita was approximately $\$ 500$ in the 1970 s and $\$ 800$ in the 1980 s. Legislation in 1990 tightened the rules, lowering the level to a $\$ 580$ per capita income in order for a country to be eligible for aid under Title III, a new grant aid program.

In keeping with this legislation, the United States no longer ships food aid to countries such as Israel and Portugal. Similarly, the EC countries, in response to the recommendations of the food aid committee operating within the Development Directorate (DG8), have shifted their food aid away from political favorites such as Malta and some of the French dependencies. And Japan has substantially stepped up its food aid toward Africa and reduced the share of its total food aid allocated to its important trading partners in Asia.

The allocation issue revolves around the question of priorities: Should not the poorest, most needy importers of food be given priority? Most groups, including commodity representatives called to testify before Congress, have found this priority hard to disavow. As a result, the donor community has raised the proportion of its food aid to these countries to approximately 90 percent. ${ }^{54}$ This does not mean, however, that allocations are never distorted by political or trade considerations. For example, both Egypt and El Salvador receive substantially more food aid than would be justified on nutritional grounds (see Table 5). Given that these countries are U.S. allies whose governments are dependent on the provision of food aid to their restless populations, it is not surprising that the United States in particular has provided them with a disproportionate amount of aid. Other countries clearly receive smaller amounts than they would if allocations were made solely on the basis of "need," as is evident in Table 5 and has also been pointed out in the studies of the IFPRI, an organization which in the 1970s began to produce periodic estimates of the needs of recipient countries.

54. See Hopkins, "Increasing Food Aid," Table 3, p. 325. According to data from the WFP "INTERFAIS," 88 percent of food aid was targeted toward "low-income, food-deficit" countries in 1990. 
The shift toward emphasizing need as a principle for allocation was reinforced in the 1980s, when the USDA began publishing its World Food Needs and Availabilities. Barbara Huddleston identified two types of needs: structural needs, which arise from perpetual deficits in a country's domestic food supply and require long-term project commitments using food, and transient needs, which arise from a sudden shortfall in supply. She and others, including Edward Clay, have also made estimates of the food need "gap" - that is, the difference between the current level of calorie intake in a country's population and the amount of food aid required to increase the intake to the level necessary for an active daily life. These gap estimates suggest that food aid should be doubled or tripled in the 1990s. ${ }^{55}$

On the one hand, a recent USDA study indicates that while needs play a large role in the allocation of food aid, particularly among donors other than the United States, they do not provide the overriding criterion for food allocations.$^{56}$ In short, allocations continue to be affected by a variety of other factors, including bureaucratic inertia, dramatic publicity such as the $1984 \mathrm{BBC}$ television documentary on starvation in Ethiopia, and, most important, persistent concerns with political and export market potential. These concerns persist in spite of the fact that the use of food aid for diplomatic or trade purposes is relatively inefficient. Moreover, they persist in the face of strong opposition both from mainstream development-oriented critics and from the more radical epistemic community that favors the abolition of all food aid or all but "emergency" aid. ${ }^{57}$

On the other hand, considerations of need have had a marked impact on the food aid allocation of various donors. Australia, for example, for a long period allocated its aid on the basis of a need-based computer model, and substantial regime reform has occurred and affected the policies of other countries, including the United States. The reform has not abolished the role of other criteria for allocation, particularly when diplomatic needs arise or become deeply embedded, as in the situation of Egypt, but it has come to dominate. In October 1990, for example, the U.S. Congress passed amendments to PL480 calling for the use of food security as the criterion for allocating major bilateral grant aid. This legislation explicitly cites measures such as levels of income and calorie intake as factors to be considered. Its aim is to prevent the executive branch of the U.S. government, when dominated by officials unresponsive to the core views of the development-oriented epistemic community, from giving priority to countries with low "needs" and succumbing to pressures from domestic interest groups whose primary objectives are domestic welfare and short-term payoffs rather than global welfare and long-term effects of food aid.

55. National Research Council, Food Aid Projections for the Decade of the 1990s.

56. Shapouri and Missiaen, "Food Aid."

57. See Rothschild, “Is It Time to End Food for Peace?”; Frances Moore Lappé, Joseph Collins, and David Kinley, Aid as Obstacle (San Francisco: Institute for Food and Development Policy, 1980); and George, How the Other Half Dies. 
Clearly, the various groups with special interests that played a large role in establishing the initial principles of the food aid regime are on the defensive and are adopting new strategies. For example, whereas the U.S. agricultural interests fought against the U.S. shipping interests in the 1960s over the issue of using food aid funds to subsidize the maritime industry by requiring that food be shipped in American (expensive) carriers, the millers and the Association of Great Lake Ports formed a coalition in the 1980s to support the food aid principles embedded in earlier U.S. legislation. In the case of food aid, as in the cases of environmental, whaling, and other issue-areas around which epistemic communities have emerged, narrow domestic interest groups have tended to form lobbies that oppose broad but less well organized interests. Classic debates along this division have occurred over food aid within legislative and executive branch agencies not only in the United States but also in the EC Commission and in donor states such as Australia and Canada. ${ }^{58}$ Policy coordination among donors, in general, has strengthened the hand of the development-oriented epistemic community and given greater exposure to its views in arguments over allocation and other issues. ${ }^{59}$

Within the larger community of activists concerned with alleviating hunger, however, two debates on the closely related issues of allocation, conditionality, and goals of food aid continue unresolved. One debate rages between those who assign top priority to emergency food aid, which has less clear long-term development value, and the members of the epistemic community, who favor an early transition from emergency feeding to development activities among refugee and famine victims. The other debate, which emerged in the 1980s in tandem with the increased use of conditionality by the IMF, World Bank, and other international funding agencies, has pitted those who oppose linking food aid with the types of conditions imposed by these agencies against the epistemic community members, who support such linkage.

\section{The conditionality of food aid}

A quid pro quo has always existed for recipients of foreign aid, including food aid. In the early years of food aid, maintaining economic and political alliances was a frequent condition. The United States, for example, provided disproportionate amounts of food aid to countries in which it had military bases. In the 1960s, conditionality was extended to agriculture and development policy. In 1966, the United States, still providing 80 to 90 percent of food

58. This claim is based on interviews held in 1984 with food aid officials in Brussels, Ottawa, Rome, and Tokyo.

59. Members of the U.S. Congress, the EC Parliament, and other legislative bodies have frequently referred to the writings of members of the epistemic community during their deliberations. This is evident, for example, in the records of various hearings before U.S. congressional committees in 1989 and 1990, prior to the passage of amendments to PL480. 
aid, enacted legislation which required that food aid recipients institute "self-help" measures. Specifically, it required them to pledge that they would use the proceeds from the sale of food shipments to improve their ability to feed their populations, either through increased local production or through investment in other projects that would enhance their economic development and provide export earnings. Coincident with this legislation, the Johnson administration placed pressure on India to change its agricultural development policies. While a change did occur in India, as evident in the country's substantial shift in policies and the high priority it gave to "green revolution technology," this was as much due to the anger and resentment generated in India in response to the U.S. conditions placed on food aid as it was to compliance with the conditions. The United States was notably less successful in coercing India into publicly supporting American involvement in the Vietnam War. ${ }^{60}$

Other recipients of food aid have occasionally reacted negatively to donor requests for reciprocation. For example, when Sukarno was governing Indonesia, his response was that the United States should "go to hell." And in the early 1960s, when the United States was providing large amounts of food aid to Egypt and placing pressures on Nasser, the ruler told the U.S. officials to "take a swim in the Nile." It is true that U.S. food aid to Egypt was abrogated between 1967 and 1973, but this was a result of the Yom Kippur War, not a failure of reciprocity, since food aid allocations to the country were in the pipeline until the war led Egypt to break diplomatic relations.

The shift to frequent use of conditionality by multilateral aid bodies in the 1980s had a spillover into food aid. IMF conditions attached to short-term loans and World Bank conditions for structural adjustment lending raised the issue of whether food aid should also be tied to macroeconomic considerations. Much to the dismay of those lobbyists who were most concerned with short-term hunger alleviation and also to the dismay of many recipient countries whose bureaucracies regularly seek to minimize the conditions placed on food aid, the development-oriented epistemic community accepted the spillover implications. In 1986, the WFP took the position that reform of food policy, associated with the structural adjustments recommended by international financial institutions, should be linked to food aid. The leaders of the UN International Children's Emergency Fund (UNICEF) argued that those countries undertaking reform should receive additional guarantees to ease their burden of adjustment and protect the sectors of their population which were most vulnerable during the economic transition entailed by macroeconomic adjustment. If government social expenditures were reduced and market interventions aimed at keeping commodity prices low were ended, then compensatory efforts to soften the social costs of adjustment on those 
most vulnerable, possibly using food aid, were in order. During the autumn 1986 meeting of the WFP Committee on Food Aid Policies and Programs, this topic was discussed at length. Developing countries, in alliance with the FAO, voiced strong opposition to any such linkages. The United States, Canada, and some of the other major bilateral donors were also skeptical of linkage. However desirable the association of food aid with economic reform might be, they argued, UN agencies lacked the discipline to allocate food in ways to support structural adjustment.

Given this opposition, the epistemic community has not yet been totally successful in establishing a clear priority for food aid to address long-term hunger problems by linkage to food policy reform, although some movement toward this goal has occurred. Beginning with the U.S. legislation mandating that recipient governments institute "self-help" measures in 1966, continuing into the U.S. Title III legislation in 1977, and following with the proposed links by the EC between food aid and national food strategies, the idea that food aid should help long-term development of food self-reliance has been increasingly adopted by donor states. It has also been adopted by various international relief and financial organizations. For example, Richard Jolly, the deputy executive director of UNICEF, has called for "adjustment with a human face." ${ }^{\circ 1}$ Similarly, the World Bank has turned its attention to the social dimensions of adjustment, created food security units within its institutional structure, and begun efforts to solicit and provide food aid through bilateral or WFP channels to various countries undertaking structural adjustment, particularly in the food sector. In countries such as Mali and Madagascar, food aid has been provided to supplement World Bank-negotiated changes in food subsidy policy. And, more recently, the PL480 legislation in 1990 called for a linkage between grant food aid and policy reform aimed at improving agriculture and food production.

These steps taken by donor governments were largely influenced by the development community, which has been particularly critical of African policies that depressed prices to producers in the 1970s and contributed substantially to the peculiar decline in many countries' per capita food production. Along with the droughts in the mid-1980s, this created the extraordinary expansion of need for food imports in Africa. Imports have in fact quadrupled in little over a decade, accompanied by a dramatic shift in food aid to Africa, as discussed earlier. Only by linking food aid with policy reform could these circumstances in Africa and similar circumstances in other recipient countries be alleviated.

Moving from rhetoric to practical implementation of rules and procedures for uses of food aid, however, requires both a transformation in donor

61. Richard Jolly, Adjustment with a Human Face (Rome: Society for International Development, 1985). Jolly called for the modification in his Barbara Ward lecture, subsequently widely quoted and reprinted. 
bureaucratic practices and a reversal of resistance in recipient countries. To a large extent, this has not happened. ${ }^{62}$ As the recent joint study of the World Bank and WFP indicates, the majority of food aid flows continue as emergency assistance or are provided with unconditional terms. ${ }^{63}$ Contrary to the advice given in the early 1980s by Edward Pisani, the head of the EC Development Directorate, little food aid is allocated with prior integration into national food policy. ${ }^{64}$ The particular interests of grain marketing agencies and bureaucrats in recipient countries, coupled with the inertia of bureaucrats in bilateral and multilateral agencies, have weakened the thrust of reform recommended by the knowledge-based food aid community. Since conditionality linkages are also unattractive to those seeking to use food aid to promote commercial trade and to diplomats looking for a quid pro quo in the form of military alliances or stability for weak but friendly governments, there is especially clear resistance to the reform effort from these groups. Despite the fact that producer prices in a number of recipient countries have moved upward, approximating or exceeding border prices, they remain low in countries such as Egypt and El Salvador, where donor state political interests guarantee the continuation of food aid and oppose quid pro quo conditionality in the area of agricultural policy. And despite the decades of rhetoric on the topic of reforming economic policies that impede local food production in recipient countries and prevent them from obtaining long-term food security, a considerable undertaking to reorganize both donor and recipient institutions remains to be accomplished.

\section{Lessons for theory and practice}

In conclusion, the food aid regime has been reshaped, following proposals from a special subset of development experts. Today, a set of widely shared norms exist for the appropriate use of food aid. According to these norms, resource transfers should take into account the effects of the aid on the food system and the economy of the recipient country. Scholarly studies and evaluations of projects undertaken with food aid conclude broadly-to the point of a scientific consensus-that food aid without sound management can have negative effects but that food aid with "appropriate" design can be extremely useful. ${ }^{65}$

62. See Raymond F. Hopkins, "Food Aid and Policy-Based Lending to Africa: Dilemmas for States and Donors," in Stephen K. Commins, ed., Africa's Development Challenges and the World Bank: Hard Questions, Costly Choices (Boulder, Colo.: Lynne Rienner, 1988), pp. 133-55; Raymond F. Hopkins, "The Evolution of Food Aid: Toward a Development-First Regime," in J. Price Gittinger et al., eds., Food Policy: Integrating Supply, Distribution, and Consumption (Baltimore, Md.: Johns Hopkins University Press, 1987), pp. 246-59; and WFP, "Review of Food Aid Programmes and Practices," document CFA/19/5, Rome, 1988.

63. World Bank and WFP, "Food Aid in Sub-Saharan Africa."

64. For a discussion of the Pisani plan, see Kees Tuinenberg, "Experience with Food Strategies in Four African Countries," in Gittinger et al., Food Policy.

65. See Jackson, Against the Grain; and Ruttan, "Food Aid." 
The fact that reform in the international food aid regime has occurred is to a significant degree attributable to the efforts of an epistemic community consisting of scholars and officials from various countries who believed that food aid could work if the original principles were changed to eliminate disincentive effects and to encourage the long-term alleviation of hunger through development-oriented projects. The community's research and arguments about the better use of food aid have been a basic force for the development of new principles that have been promulgated in authoritative statements such as those issued in 1979 by the WFP Committee on Food Aid Policies and Programs and reinforced in 1986 and 1988 studies by the World Bank. ${ }^{66}$

From the four case studies of food aid reform reviewed above, two lessons can be drawn, each of which bears on the argument that ideas and new knowledge, especially as they arise from and are nurtured by an epistemic community, play independent and occasionally powerful roles in changing international regimes and international politics. The first lesson is that incremental change can occur when the consensual views of an epistemic community diverge from the politically modal position of the supporters of a policy. Synoptic change, however, is not plausible. Turbulent conditions, as in the 1973-74 period, can accelerate change, but when the larger world economic order is not dissolving, the dominant pattern is incremental adjustment. As Robert Rothstein had concluded with regard to international reform in recent decades, consensual knowledge breeds incremental, not radical, change. ${ }^{67}$

The second lesson is that the locus for the construction and change of a food aid regime has shifted from an American-centered one in the 1950 s to a more international one. Although actions by the U.S. government, the founder of the food aid regime and the major contributor of resources, and by Americans unaffiliated with the government have played a substantial role in changes in the rules and regulations, the new knowledge about world food needs and about effective uses of food aid has emerged globally. Indeed, following the turbulences of 1973-74, leadership in food aid research and practical innovations, along with a concern for efficient world agricultural production, has emerged most markedly from non-American sources. For instance, while the domestic goal of surplus disposal has lingered in the United States, other donor states have more fully embraced the idea of targeting nonsurplus food aid toward the broader goal of meeting the food security needs of specific recipient states. ${ }^{68}$ Moreover, in recent decades, most of the ideas for reform in food aid principles and norms have arisen from international bodies such as the WFP and IFPRI or from European scholars who increasingly have taken the leadership role in the epistemic community focused on food aid.

66. See WFP, "Guidelines and Criteria for Food Aid," document CFA/7/5, Rome, adopted in 1979; World Bank, Poverty and Hunger; and World Bank, The Challenge of Hunger in Africa: A Call. to Action (Washington, D.C.: World Bank, 1988).

67. Robert Rothstein, "Consensual Knowledge and International Collaboration," International Organization 38 (Autumn 1984), pp. 733-62.

68. Shapouri and Missiaen, "Food Aid." 